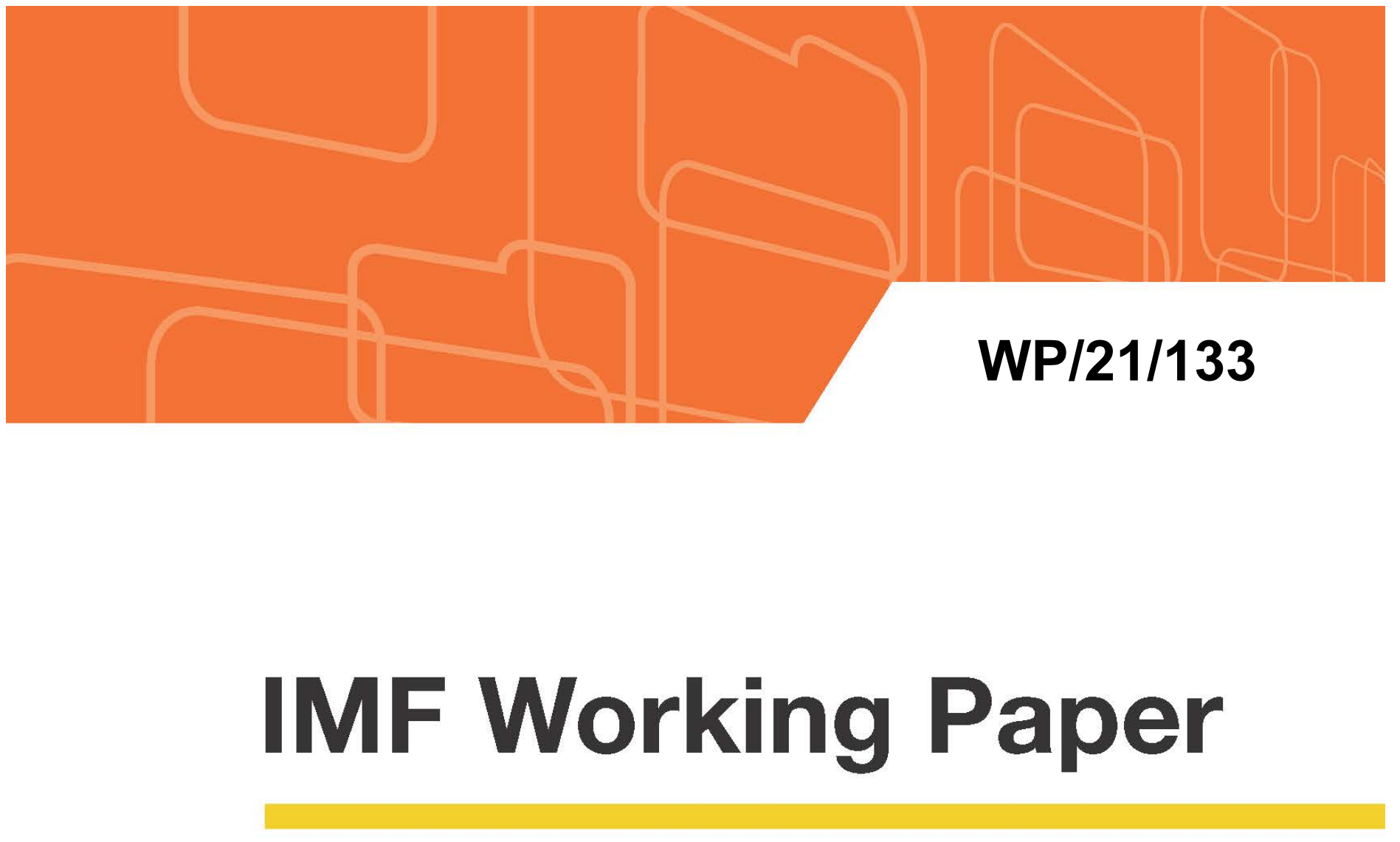

\title{
Avoid a Fall or Fly Again: Turning Points of State Fragility
}

by Olusegun Akanbi, Nikolay Gueorguiev, Jiro Honda, Paulomi Mehta, Kenji Moriyama, Keyra Primus, and Mouhamadou Sy 


\title{
IMF Working Paper
}

Fiscal Affairs Department

Avoid a Fall or Fly Again: Turning Points of State Fragility

\section{Prepared by Olusegun Akanbi, Nikolay Gueorguiev, Jiro Honda, Paulomi Mehta, Kenji Moriyama, Keyra Primus, and Mouhamadou Sy ${ }^{1}$}

May 2021

\begin{abstract}
IMF Working Papers describe research in progress by the author(s) and are published to elicit comments and to encourage debate. The views expressed in IMF Working Papers are those of the author(s) and do not necessarily represent the views of the IMF, its Executive Board, or IMF management.
\end{abstract}

\begin{abstract}
High persistence of state fragility (a fragility trap) suggests the presence of substantial benefits from avoiding a fall into fragility and considerable hurdles to successful exit from fragility. This paper empirically examines the factors that affect the turning points of entering and exiting from state fragility by employing three different approaches: an event study, the synthetic control method, and a logit model. We find that avoiding economic contraction is critical to prevent a country on the brink of fragility from falling into fragility (e.g., among near fragile countries, the probability of entering fragility would rise by 40 percentage points should real GDP per capita growth decline from +2.5 percent to -2.5 percent). Also, strengthening government effectiveness together with increasing political inclusion and maintaining robust economic activity should help make exit from fragility more successful and sustainable. In the current environment (the COVID19 crisis and its aftermath), the findings suggest the importance of providing well-directed fiscal stimulus with sufficient financing, (subject to appropriate governance safeguards and welldesigned policies), and protecting critical socio-economic spending to keep vulnerable countries away from being caught in a fragility trap.
\end{abstract}

JEL Classification Numbers: E62, O10, P48.

Keywords: Fragile and Conflict-Affected States, fragility trap, pivotal moments.

Authors' E-Mail Addresses: OAkanbi@imf.org; NGueorguiev@imf.org; JHonda@imf.org; pmehta3@ifc.org; KMoriyama@imf.org; KPrimus@imf.org; MSy@imf.org.

\footnotetext{
${ }^{1}$ We are grateful for helpful comments and suggestions from participants of IMF's Fiscal Affairs Department seminar, as well as various IMF staff. We would also like to thank Isaura Garcia Valdes for research assistance.
} 
A. Definition of State Fragility: Literature and our Approach

B. Determinants of State Fragility and Policies to Address Fragility

C. Recent Studies to Address a "Fragility Trap": Any Asymmetry and Implications?

V. EMPIRICAL RESULTS

A. Event Study Analysis

B. Synthetic Control Method (SCM)

C. Logit Model

FIGURES

1. Event Studies: Political Competition and Executive Constraints 16

2. Event Studies: Health and Education Spending and HDI

3. Event Studies: Health and Education Spending in percent of Overall Spending 18

4. GDP Per Capita Developments for Identified Events

5. The Determinants of Entry/Exit from Fragility 24

6. Nexus of Growth and Government Effectiveness 26

\section{APPENDICES}

I. Definitions of Fragile States in IFls and Key International Actors 35

II. Data Sources

III. Regression Tables: Entry and Exit Events, Logit Model _____ 38

IV. Entry Cases

V. Exit Cases 43

VI. Entry Counterfactuals 44

VII. Exit Counterfactuals 45

VIII. Case Studies 46 


\section{INTRODUCTION}

Fragile and conflict-affected States (FCS) are defined as countries trapped in cycles of low administrative capacity, political instability, conflict, and weak economic performance (IMF, 2015). These structural problems preclude the formation of robust governing systems and hinder institution building. The legacy of weak governance and conflict has locked FCS into a dysfunctional but stable equilibrium, or "fragility trap" (Collier, 2020). Given the complexity and multi-dimensional aspects of fragility, which interact and reinforce one another in a vicious circle, transition out of such equilibrium would be inherently difficult.

Both literature and data, summarized later in the paper, suggest that state fragility is highly persistent, with high risk of relapses. Dynamics of state fragility do not always move in a linear manner. For example, FCS can start off in conflict/disaster, move to post-conflict/postdisaster, then fall back into conflict. The probability of remaining fragile could be higher than that of exiting from fragility, because a country trapped into state fragility would find it very difficult to improve on all fronts-including economic performance, governance, political stability and institutional quality - at the same time. Also, different factors could affect entry into and exit from fragility in a different way.

These asymmetries are emphasized in recent studies that have focused on how to address the fragility trap. The inherent institutional weaknesses in FCS perpetuate fragility. ${ }^{2}$ The "fragility trap" is a closely interlinked circle of underdevelopment, political instability or conflict, and ineffective state capacity (e.g., Gelbard et al., 2015; Deléchat et al., 2018). These studies emphasize the nexus between the so called "slow moving" factors (e.g., significant institutional and policy weakness) and "fast moving" factors (e.g., political conflict, exogenous shocks, and economic/social stability). This nexus could create different dynamics at the turning points of state fragility (entering and exiting from fragility).

\section{Investigating factors that affect turning points is a very relevant and timely topic for LICs in the current pandemic-affected economic and social environment. Unlike advanced economies (AEs), many developing countries do not have sufficient financial buffers and access to financing, while suffering from severely underdeveloped institutions, social safety nets, health systems, and financial markets. On top of all this, at present they are facing adverse and}

\footnotetext{
2 This paper follows IMF (2002 and 2019) on the definition of institutional capacity: it is country's administrative and management capacity, particularly with respect to implementing economic policies. This includes the ability to collect statistical information needed for effective policy implementation, effectively plan government expenditure and delivery of public services, effectiveness of agencies to fight corruption and enhance governance, the establishment and operation of appropriate regulatory frameworks, and the making and enforcement of rule of laws and judicial reforms (IMF, 2019).
} 
correlated exogenous shocks (the pandemic, falls in commodity prices and remittances etc.). These countries are therefore more vulnerable to shocks and thus face bigger challenges on multiple fronts in tackling COVID-19 and its economic spillovers than AEs. Against this background, studying the factors that affect turning points of state fragility is of high policy and operational importance for the countries' policy makers and the IFIs.

\section{This paper will contribute to the literature by empirically examining the factors that affect} turning points of state fragility. Specifically, this study will explore: (i) what factors push a country into fragility; (ii) what factors contribute to get FCS out of fragility; and (iii) what factors can help former FCS stay out of fragility and sustain good economic performance. First, the paper will identify events where countries entered/exited fragility using a large dataset consisting of 196 countries spanning from 1979 to 2018. Second, given empirical challenges posed by the small numbers of identified events, the other side of a coin of the persistence of state fragility, we will use the technique of defining counterfactuals and using them in the empirical analysis. Third, the paper will employ three different methodologies to conduct the empirical analysis: (i) event studies, which are conducted for a wide range of indicators to identify systematic differences across different groups; (ii) the synthetic control method (SCM), which is applied to find systematic differences across identified entry/exit events and counterfactuals; and (iii) a logit model which estimates the conditional probability of entry/exit. These three different methodologies should make our analysis and findings more robust.

\section{The key messages, based on the findings of this paper, are the following:}

- The persistence of state fragility suggests considerable hurdles to a successful exit from fragility, and at the same time indicates substantial benefits of avoiding fragility in the first place. Reflecting asymmetries in the factors affecting turning points, different policies are needed to avoid falling into fragility and foster exiting from fragility.

- When a country is on the brink of falling into fragility, policies should focus on avoiding economic contraction. In FCS, the lack of development of financial markets may constrain the effectiveness of monetary policy instruments. On the fiscal policy front, on the other hand, this could be achieved by: (i) using previously accumulated buffers; (ii) obtaining external financing, or (iii) both, while strengthening the effectiveness of spending and reducing fiscal risks associated with the spending. The first option requires maintaining prudent macro policies to build up sufficient buffers before a country is close to fragility. ${ }^{3}$ For the second option, the international community should provide financing subject to appropriate safeguards and policy design, such as adopting measures to make effective use of the

\footnotetext{
${ }^{3}$ Gelbard et al. (2015) finds the criticality of building buffers of government savings and external reserves for building resilience in fragile countries.
} 
provided resources with sufficient transparency and accountability and tackle governance and corruption weaknesses (e.g., IMF, 2018).

- To escape from the fragility trap and make the exit sustainable, strengthening government effectiveness, enhancing political inclusion, and increasing social/education spending could play a critical role. Stronger political and social inclusion would increase the traction of implemented reforms and macroeconomic policies by the government. Better economic outcomes and capacity, supported by appropriate reforms and policies, should raise tax revenue that could be used to finance social spending as well as infrastructure to further enhance social and political inclusion. Such virtuous cycle should make a country's escape from fragility sustainable.

- Moreover, clear departure from the pre-fragility system, including political and social inclusion, could help sustain the exit from fragility through fostering better economic outcomes. Such departure could further propel the virtuous cycle through strengthening traction of reforms by the government and political support for the reforms. Effectively using the opportunity of "pivotal moments" to embrace a new approach, seeking more political and social inclusion, could help FCS achieve escape and a sustainable exit from fragility. ${ }^{4}$

The rest of the paper is organized as follows. Section II presents a review of the literature on the determinants of fragility and recent studies on a "fragility trap." Section III briefly discusses the empirical strategy employed in the paper. Section IV describes the data, including the identified turning points and their counterfactuals. Section $\vee$ presents the results of three empirical approaches: an event study, the synthetic control method, and a logit model. The final section provides concluding remarks and policy recommendations.

\section{Literature ReVIEW}

\section{A. Definition of State Fragility: Literature and our Approach}

While there are many ways to define fragile countries, reflecting its complexity, they seem to have common characteristics (IMF, 2008). These include: (i) significant institutional and policy implementation weakness; (ii) a fractious political context; (iii) severe domestic resource constraints; and (iv) high vulnerability to shocks (e.g., IMF, 2012).

However, there is no universally accepted operational definition of "fragility" to conduct empirical studies. The complex and multidimensional nature of state fragility has militated

\footnotetext{
${ }^{4}$ As discussed in Section IV, at "pivotal moments," the government may be willing to face the reality that past policies have failed and the new approach must be taken.
} 
against a strict definition of FCS, with various definitions used by different institutions and scholars (Appendix I provides a summary of operational definitions used in different institutions).

- In most of the academic studies, states are considered as fragile when their weak institutional capacity, political instability and weak governance severely limit the state's ability to guarantee security to its citizens and deliver basic public services. For example, Collier (2020) suggests the following characteristics of a fragile state: little or no overarching shared identity, lack of state legitimacy, lack of capacity, existential uncertainties, underdeveloped private sector, and high exposure to political and economic shocks. Acemoglu and Robinson (2021) define a fragile state by the strength of its capacity and its political regime. Limited political and institutional ability to implement appropriate policies to address structural challenges and exogenous shocks have resulted in weak economic performance, chronic humanitarian crises, persistent social tensions, and often violence or the legacy of armed conflicts in fragile states.

- On the other hand, in most of the empirical studies, state fragility is defined empirically as low Country Policy and Institutional Assessment (CPIA) scores or high values of a fragility index. ${ }^{5}$ In most of the IMF/World Bank (WB) papers, state fragility is defined as having either weak institutional capacity as measured by the World Bank's CPIA score (average of 3.2 or lower) or experience of conflict (signaled by the presence of a peace-keeping or peace-building operation in the most recent three-year period). Recent work by the OECD breaks down the drivers of fragility for each country and reveals different patterns of vulnerability. ${ }^{6}$ While sensible, this approach requires very big datasets and does not provide a long time series. In most cases, fragile countries have limited data, making the compilation of data with sufficient coverage of countries and time periods very challenging.

\section{Given the above, this study follows the definition used for operational and analytical work by the WB and the IMF. It is based on the CPIA ratings and the presence of UN and regional peace keeping and peace building operations (PKO/PBO). 7,8 There are a couple of advantages in}

\footnotetext{
${ }^{5}$ The fragility index is given as the average of six indicator clusters: governance; economics; security; human development; demography; and environment (see Carment et al., 2008, 2011).

${ }^{6}$ OECD (2015) identifies five dimensions of risk and vulnerability linked to fragility: (i) violence (peaceful societies); (ii) access to justice for all; (iii) effective, accountable and inclusive institutions; (iv) economic foundations; (v) capacity to adapt to social, economic and environmental shocks and disasters.

${ }^{7}$ The WB's CPIA assesses the quality of a country's present policy and institutional framework. "Quality" refers to the framework's ability to foster poverty reduction, sustainable growth, and the effective use of development assistance. The 16 CPIA criteria are grouped into four clusters: Economic Management, Structural Policies, Policies for Social Inclusion and Equity, and Public Sector Management and Institutions. For each criterion, countries are rated on a scale of 1 (low) to 6 (high). A 1 rating corresponds to a very weak performance, and a 6 rating to a very strong performance.

${ }^{8}$ As per the WB methodology, a country is classified as fragile if it has (i) a harmonized CPIA country rating of 3.2 or less, and/or (ii) the presence of a UN and/or regional peace-keeping or political/peace-building mission during the last three years. Political and Peace-Building Missions are specifically defined as the presence of a UN and/or regional organization (for example: AU, EU, NATO) in the country in the last three years. Also, the WB's FCS list includes only IDA eligible countries and non-member or inactive territories or countries without CPIA data.
} 
this approach. First, using the WB and IMF definition makes this study's results operationally relevant for both institutions. Second, it can be applied more or less consistently backwards to the late 1970s, which would enable us to have a wider data coverage. This is not the case for almost all of the other definitions. Third, the definition covers both "slow moving" aspects of state fragility (by the CPIA component) and "fast moving" aspects (by the PKO/PBO one)—see below for detailed discussion on the two aspects. In any event, the empirical strategy employed in the paper could be applied to datasets compiled by any definition, subject to data availability.

\section{B. Determinants of State Fragility and Policies to Address Fragility}

\section{Understanding the nature and drivers of fragility is important to devise policies that will}

help countries. Many theoretical and empirical studies have examined the determinants of state fragility to identify the manifestations and a better understanding of state fragility to inform policy making. Meanwhile, IFIs have worked closely with the authorities in fragile countries to help them to strengthen capacity.

\section{Theoretical studies found political instability and violence, insecurity, weak institutions,} and corruption as key drivers of FCS. Vallings and Moreno-Torres (2005) noted that weak institutions are the central driver of state fragility, relative to economic factors. Kaplan (2008) pointed out that fragile states have two structural problems, political identity fragmentation and weak national institutions, which reinforce each other. Andrimihaja et al., (2011) noted that three features-political instability and violence, insecure property rights and unenforceable contracts, and corruption-conspire to create a slow-growth-poor-governance equilibrium.

On the other hand, empirical studies found macroeconomic variables, institutions, predetermined factors, and social indicators as major determinants of fragility. Feeny et al., (2015) found that macroeconomic variables such as income levels and economic growth are important determinants of state fragility. Similarly, poorer countries tend to be more fragile than richer countries on average and countries that are more open to trade tended to be less fragile (Carment et al., 2008, 2011). Also, some studies identified weak institutions as the main determinants of state fragility. For example, Bertocchi and Guerzoni (2012) used probit regressions to identify that restrictions of civil liberties and the number of revolutions raise the probability of fragility in Sub-Saharan African countries. Predetermined factors affect too, including: country size (Feeny et al., 2015); and ethnic risk and ethnic diversity (Carment et al., 2008). Also, state fragility depends on social indicators, including low values of the Human Development Indicator (HDI), higher infant mortality rates, and a lower level of education (Feeny et al., 2015; Carment et al., 2008, 2011).

Some studies found the importance of strengthening institutions and governance in crafting policies to tackle fragility. There is in general no one-size-fits-all approach to 
addressing fragility, given that FCS are hererogeneous in their economic structure, sources and degree of fragility, and macroeconomic performance (IMF, 2017a). Therefore, specific policies to address fragility need to take into account country-specific circumstances and reflect the country's degree of fragility (Baer et al., 2021). Case studies have so far provided useful insights. For example, enhancing the capacity to mobilize revenues more efficiently and strengthening control in budget and financial management helped countries to exit from fragility (IMF, 2017b). Fiscal institutions and fiscal space are significantly and robustly associated with building resilience (Delechat et al., 2018). Absorptive capacity constraints hinder capacity building from delivering real and lasting institutional change (IMF, 2012; 2015). Benefits of capacity development support to fragile state could be enhanced by increasing the use of on-the-ground experts, employing realistic impact assessment tools, and making efforts to secure adequatre financial resources for capacity building (IMF IEO, 2018). It is also important to develop forwardlooking, holistic country strategies and practical steps that integrate the roles of policy advice, financial support and capacity building. Moreover, greater flexibility should be built into program design and more attention to the political economy in Fund supported arrangements for fragile countries (IMF, 2011). An evaluation conducted by the World Bank Group in 2016, based on case studies, emphasized that strengthening legitimate institutions and governance to provide citizen security, justice, and jobs is crucial to break cycles of violence and help restore stable development path in fragile countries.

\section{Recent Studies to Address a "Fragility Trap": Any Asymmetry and Implications?}

\section{Recent studies on state fragility emphasize the persistence of state fragility ("fragility trap") caused by the nexus of politics, institution building social or economic inclusion, and economic policies. Fragile countries may be further entrenched by the reinforcing} interactions between fragility, economic and political instability, and daunting structural challenges, such as poor governance, weak institutional capacity, and lack of political and social inclusion (IGC, 2018). This emphasizes the importance of addressing both slow-moving and fastmoving factors to avoid being trapped by and facilitating exit from state fragility. The slowmoving factors include significant institutional and policy implementation weaknesses. In this context, departing from "extractive" political and economic systems that impede economic growth (Acemoglu and Robinson, 2012) and policy intervention to change institutional, political and economic structure should help countries avoid fragility as well as facilitate exit from it. ${ }^{9}$ On the other hand, the fast moving factors include political conflict, exogenous shocks, and economic/social stability, including economic policy errors, that could affect state fragility and push a country over the cliff toward fragility (Vallings and Moreno-Torres, 2005; Gelbard et al.,

\footnotetext{
${ }^{9}$ According to Acemoglu and Robinson (2012), extractive economic institutions lack secure property rights and economic opportunities not just for the elite but for a broad cross-section of society. On the other hand, extractive political institutions are not sufficiently centralized and pluralistic.
} 
2015). Other studies found that building tax capacity could support state building, improve institutional capacity, and foster economic development (Besley and Persson, 2010; Gaspar et al., 2016a, 2016b; and Akanbi, 2019).

The nexus of the two factors also suggests considerable hurdles for successful exit from a fragility trap, with substantial benefits of avoiding fragility in the first place. Acemoglu and Robinson (2019) argue that exiting from fragility requires empowering both the state and the society to create a strong and inclusive state. Meanwhile, Besley and Persson (2011b) and Collier (2020) argue for the criticality of policy intervention and institution building, especially at a critical juncture (a "pivotal moment"). Relatedly, Hegre et al., (2017) pointed to the oversized influence of conflict in low-income countries: (i) a single onset of conflict could be enough to push the country into the trap; and (ii) even a couple of years refraining from a major conflict will reduce the risk of conflict over the next decades substantially.

\section{Recent studies indicate the need of a new framework to secure development in FCS at the} brink of entering or entrenched in "fragility trap." Zoelick (2008) noted that a new framework is required which involves building security, legitimacy, governance, and economy. After identifying specific traps-the conflict trap; the natural resources trap; the trap of being landlocked with bad neighbors; and the trap of bad governance in a small country, Collier (2007) concludes that a new mix of policy instruments is required to escape from these traps, where (i) the policy mix for tackling these traps should include: aid; security; laws and charters; and trade policies but (ii) aid should not be viewed as the main solution because it is unable to stop conflict although it can help after a conflict has ended. Other studies support this: aid only works in good policy environments, and weak absorptive capacity as well as the failure of conditionality to buy reforms hinder the effectiveness of aid in FCS (Burnside and Dollar, 2000; Carment et al., 2008). ${ }^{10}$ Smarter demand-driven aid modalities and instruments should therefore be implemented (OECD, 2015).

\section{A Gap: Factors Explaining the Turning Points}

Past studies examined the root causes of fragility rather than the turning points. A review of the literature reveals that previous theoretical and empirical studies have focused on the common characteristics of countries in fragile situations and the determinants of fragility. Meanwhile, IFIs have focused on how to improve engagement to help build capacity in fragile countries. There is, however, a dearth of literature on what causes countries to enter into and exit fragility, or turning points, as well as how to stay out of fragility after exit. Moreover, currently, many low income countries close to fragility or those that exited fragility during 2017-2019 have

\footnotetext{
${ }^{10}$ Andrimihaja et al., (2011) also point out that even though aid is unproductive in weak governance environments, it could be beneficial if it is invested in such a way that helps these countries tackle the root causes of fragility-instability, insecurity and corruption.
} 
faced the huge exogenous shocks from the COVID-19 pandemic and its economic spillovers. It is therefore important for policymakers to understand the factors that can prevent their countries from falling into fragility and the measures which can be implemented to exit the fragility trap. This study aims to analyze these issues.

\section{EMPIRICAL Strategy}

Persistence of state fragility poses a big challenge in empirical analyses of factors that affect direction-changing turning points (entry of and exit from state fragility). We need a large number of observations to conduct meaningful analyses, especially when applying econometric methods based on asymptotic properties. However, as suggested by the literature, high persistence of state fragility may inherently limit the number of turning points. Therefore, simply running panel regressions with entry/exit event dummy on the left hand side and possible determinants on the right hand side for a data set of LICS (a method largely deployed in the empirical literature on the determinants of state fragility) may not give meaningful results for our purposes, because the average probability of entering/exiting fragility in any given year is low.

\section{Our paper will, therefore, construct "counterfactuals" of the entry/exit events and} systematically analyze the relation between the identified events and their counterfactuals. Given the limited number of entry or exit events, we will compare the identified events to their counterfactuals. Counterfactuals are cases (country-periods), when a country should have entered into fragility, but did not; or it should have exited from fragility but did not.

\section{Overall, we will employ three empirical approaches to enhance the robustness of our} analysis. Data availability and the number of observations may constrain effective application of usual empirical techniques, like using large cross country or panel data to run regressions on the identified entry or exit events, even after considering suitable counterfactuals. Therefore, we will use three different approaches to explore what factors affect turning points: pushing a country into fragility; getting FCS out of fragility; and making the exit from fragility more sustainable with good economic performance. The three approaches include: (i) conducting event studies to identify any systematic differences across different groups; (ii) applying the synthetic control method (SCM) to identify any systematic differences in macro and institutional indicators across different groups; and (iii) estimating the conditional probability of entry or exit by a logit model. Using these multiple methodologies will help make our results more robust.

\section{Data: Turning Points, Pivotal Moments and Other Data}

\section{As discussed in Section II, the paper generally follows the WB/IMF definition of a fragile} and conflict state, with some extensions. The paper takes into consideration the fact that often the presence of peacekeeping or peacebuilding forces may not accurately identify the period of 
conflict as in many cases these forces were deployed after the conflict subsided. To address this issue, a third criterion is introduced-named "conflict", where "conflict" periods are identified based on the number of deaths (in the Uppsala database) as a percent of population. Thus, a country can be classified as fragile if: 11,12

- its rolling average CPIA over the last three years is below 3.2; or

- it has had a UN or regional peacekeeping or peacebuilding force on its territory in the most recent three years; or

- it has conflict, defined as being in the top 25 percentile of all countries in terms of deaths as a proportion of the previous year's total population.

\section{Moreover, the paper expands the sample to include countries that used to be low income/lower middle income, given the availability of CPIA data (1977 to 2018). ${ }^{13}$ Our} samples therefore include 128 countries spanning from 1977 to 2018.

\section{We identified 83 entry and 52 exit events based on the above definition (Text table 1).} Since the paper focuses on turning points, we need to identify the time period when a country enters into and exits from fragility. An entry event is defined as the first instance of fragility, based on the above definition, that is followed by three consecutive years of fragility. On the other hand, an exit event is the first instance of non-fragility that is followed by three consecutive years of non-fragility. ${ }^{14}$ The identified entry and exit events are summarized
Text Table 1. Identified Entry/Exit Events (since 1981)

\begin{tabular}{lcc}
\hline & Entry & Exit \\
\hline Total & 83 & 52 \\
of which, 1/ \\
$\begin{array}{l}\text { Exit/return to fragility } \\
\text { within 10 years } \\
\begin{array}{l}\text { Stay in fragility/exit } \\
\text { even after 10 years }\end{array}\end{array}$ & 30 & 15 \\
\hline
\end{tabular}

1/ Differences (14 for entry and 9 for exit) are the cases entered/exited from fragility recently (after 2008).

\footnotetext{
${ }^{11}$ CPIA scores were only available for low-income countries. There was also no comprehensive database of UN and other peace keeping missions.

12 In the first bullet, the CPIA score of 3.2 stands as the cut-off point for entry (below 3.2) and exit (above 3.2) events. This score is based on the average of last three years is in line with the IMF/WB definition of state fragility. In the third bullet, using the previous year's population aims to prevent a large number of casualities that could affect total population from distorting the ratio. Note that the Uppsala data are only available from 1989 and thus this criterion is only applied to identify conflict in countries starting in 1989. Before that, identifying the events is based on the first two bullets (however, this should not severely affect the feasibility of our empirical analyses because most of the indicators used for our empirical studies do not have data before 1995).

${ }^{13}$ For the years prior to 1997 , data followed a 1-5 scale which was then rescaled to match the 1-6 scale followed in the years after 1997.

${ }^{14} \mathrm{~A}$ full list of entry and exit events is available in Appendices IV and V.
} 
in Text Table $1 .{ }^{15}$ While about $1 / 3$ of the identified entry events exited from fragility within 10 years, the remaining $2 / 3$ of the entry events stayed in fragility even after 10 years. This is in line with the persistence of state fragility ("fragility trap") reported in the literature. Moreover, 30 percent of the identified exit events came back to fragility within 10 years after the exit. This suggest the importance of addressing factors that could help make exit sustainable.

\section{We find $\mathbf{4 5}$ counterfactuals for the identified entry events and $\mathbf{4 2}$ for the exit events (Text}

Table 2). ${ }^{16}$ Entry counterfactuals are defined as

countries which should have had an entry event but did not, while exit counterfactuals are those countries which should have had an exit event but did not. The paper uses three of the six components that constitute the World Governance Indicators (WGI)—government effectiveness and regulatory quality that have high

Text Table 2. Entry/Exit Events and their Counterfactuals, after 1995

\begin{tabular}{lcc}
\hline & Identified events & Counterfactuals \\
\hline Entry & 41 & 45 \\
Exit & 27 & 42 \\
\hline
\end{tabular}
correlation with the CPIA, and political stability, which could be a proxy for conflicts. ${ }^{17}$ We define an entry counterfactual as at least one of the three components of the WGI below their $40^{\text {th }}$ percentile but the country is not in fragility during period $\mathrm{T}$ to $\mathrm{T}+3 .{ }^{18}$ An exit counterfactual is

\footnotetext{
${ }^{15}$ In the case of entry into fragility, 3/4 of the cases are due to low CPIA scores, about 20 percent due to peace keeping or peace building missions, and 7 percent to conflict as defined above. For exit, about 80 percent are due to an improvement in CPIA scores. For entry/exit cases due to changes in CPIA scores, only 5 percent of entry cases and 20 percent of exit cases change by less than 0.2 from $T-3$ to $T+3$ (for the latter, 10 percent change by less than 0.1 ), suggesting that the identified events are not so much distorted by a small change near the threshold of 3.2 .

${ }^{16} \mathrm{~A}$ list of these counterfactuals can be found in Appendices VI and VII. It should be noted that the same country can be both in the identified turning points and the counterfactual group depending on the year. For example, Azerbaijan was an entry counterfactual in 2002; and a fragile case from 1992 to 1995.

${ }^{17}$ According to the World Bank (http://info.worldbank.org/governance/wgi/Home/FAQ), the dimension on political stability captures perceptions of the likelihood of political instability and/or politically-motivated violence, including terrorism. Government effectiveness captures perceptions of the quality of public services, the quality of the civil service and the degree of its independence from political pressures, the quality of policy formulation and implementation, and the credibility of the government's commitment to such policies. Regulatory quality captured perceptions of the ability of the government to formulate and implement sound policies and regulations that permit and promote private sector development. CPIA has a high correlation with regulatory quality $(0.70)$ and government effectiveness $(0.69)$, suggesting the importance of the quality of institutions and the ability of the government to implement sound policies. The correlation coefficient shows that there is a moderate relationship with CPIA and rule of law (0.57), control of corruption (0.48), voice and accountability $(0.40)$, and political stability and absence of violence $(0.38)$. Also, conflict has a negative correlation to political stability and absence of violence and government effectiveness (-0.58 and -0.48 , respectively).

${ }^{18}$ We use the $40^{\text {th }}$ percentile as this is in keeping with the CPIA methodology of using 3.2 as a threshold for fragility which is also the $40^{\text {th }}$ percentile in the countries' ranking (IMF, 2008). We then identify the countries and years in which the value of these three indicators was less than the $40^{\text {th }}$ percentile. If this coincides with a period of non-fragility and the country remains non-fragile for the next three years, that country-year combination is then identified as an entry counterfactual. Similar discussion applies to exit counterfactuals.
} 
defined as that with at least one of the three WGI indicators greater than the $40^{\text {th }}$ percentile but the country is staying in fragility during period $T$ to $T+3 .{ }^{19,20}$

\section{This study is also the first to compile cross country panel data of "Pivotal moments"} (Collier, 2020). In "Pivotal moments," the government may be willing to face the reality that past policies have failed and a new approach must be embraced. As highlighted before, recent literature discusses that such moments could fundamentally transform political and economic institutions, supporting the country's exit from fragility. In this study, we follow the formulation by Collier (2020): "pivotal moments usually come after a crisis or a change of leadership." Specifically, we define "pivotal moments" as the occurrence of a crisis, according to the dataset compiled by Laeven and Valencia (2018), or change in executive power in LICs and lower tier of middle-income countries taken from Wilson (2019)'s Cross National Time Series Data Archive to identify changes in the effective executive. It is worth noting that "pivotal moments" provide an opportunity for a fundamental change in the country's economic and political course, but do not guarantee it—not every such moment leads to a lasting exit from fragility. ${ }^{21}$ This feature can be explored to identify other conditions that magnify the power of these "pivotal moments".

Other data are taken from the usual sources. Macroeconomic data for the empirical studies come from the IMF's World Economic Outlook whereas data on various social indicators such as health expenditure, military expenditure and education expenditure are taken from the World Bank's World Development Indicators database (see Appendix II). However, revisions of macroeconomic data in low-income countries have been more frequent and, in some cases, larger, compared to other income groups (Ley and Misch, 2014), suggesting the interpretation of the results of empirical studies should be careful.

\section{EMPIRICAL ReSULTS}

This section presents the results of three empirical approaches: (i) an event study analysis; (ii) the synthetic control method (SCM); and (iii) a logit model to investigate factors that affect entry in/exit from fragility.

\footnotetext{
${ }^{19}$ Among the three indicators, political stability has the strongest power to determine the identified counterfactual (much higher than other two factors), measured by the share of the cases with the value higher (or lower) than the threshold.

${ }^{20}$ We impose one additional constraint: at least three-year interval between the identified counterfactuals.

${ }^{21}$ For example, a change in executive power that leads to a more authoritative government could delay a country's exit from fragility. Also, a delayed recovery from a financial crisis could further hurt the traction and credibility of the government policies, making fundamental reforms and exit from fragility more difficult.
} 


\section{A. Event Study Analysis}

We conduct event studies on a wide range of indicators. These include: (i) institutional and governance indicators (e.g., Polity IV and change in executive powers); (ii) pivotal moments; (iii) macroeconomic indicators (e.g., GDP growth and inflation); (iv) fiscal indicators (e.g., tax revenue, government expenditure, education expenditure, military expenditure, health expenditure, and capital spending); (v) social indicators (e.g., HDI, infant mortality, and life expectancy); and (vi) shocks (e.g., terms of trade, natural disasters, conflicts, and financial crises). These indicators were used in a pairwise comparison of the identified entry/exit events to their counterfactuals to check for any meaningful difference between them. ${ }^{22}$ The Mood's median test is used to test whether the difference between the two medians is statistically significant (if the number of observations allows it). While event studies cannot escape endogeneity concerns, to minimize the effects of endogeneity, we focus on developments of indicators during T-4 and T-2 (where Year T is the identified year of entry into or exit from fragility) in most of the analysis. In the paper, we report the economically important results with statistically significant differences; the rest are available upon request.

\section{The results from the event studies show important differences between the identified entry/exit events and their counterfactuals for several indicators: ${ }^{23}$}

- Political competition affects entry into fragility as well as sustained exit from fragility (Figure 1). By construction, the political competition variable could be regarded as a proxy for political inclusion. ${ }^{24}$ The result of the Mood's median test shows that the identified events and their counterfactuals have statistically-significant different medians. ${ }^{25}$ This may reflect that more political competition could facilitate a departure from "extractive" political and economic systems that impede economic growth (Acemoglu and Robinson, 2012). On the other hand, executive constraints, a measure of the strength of the executive vs. other institutions, do not appear to differentiate identified entry and exit events from their counterfactuals before the events. However, sustained exit cases have stronger executive constraints than those returning to fragility after they exited from fragility $(T+2-T+4)$-the median test indicates the difference is significant at 10 percent level (Figure 1). While its

\footnotetext{
22 The event study analysis divides the identified cases and their counterfactuals into 16 groups, depending on their duration and conditions prior to the entry/exit.

${ }^{23}$ These results should be interpreted with caution, as the methodology controls only for the timing of entry/exit and duration of fragility/exit.

24 Political Competition and Opposition in the Polity IV dataset measures the "political competition" concept in two ways: (i) by the degree of institutionalization or "regulation" of political participation; and (ii) by the extent of government restriction on political competition.

25 Mood's median test is a two-sample version of the sign test. See https://psych.unl.edu/psycrs/handcomp/hcmedian.PDF.
} 
interpretation should be careful (because it may be contaminated by endogeneity), this observation implies that more institutionalized constraints on the decision making powers of executives at the early stage of exit could help countries to sustain exit from fragility, perhaps through making recovery/economic activity more private-driven.

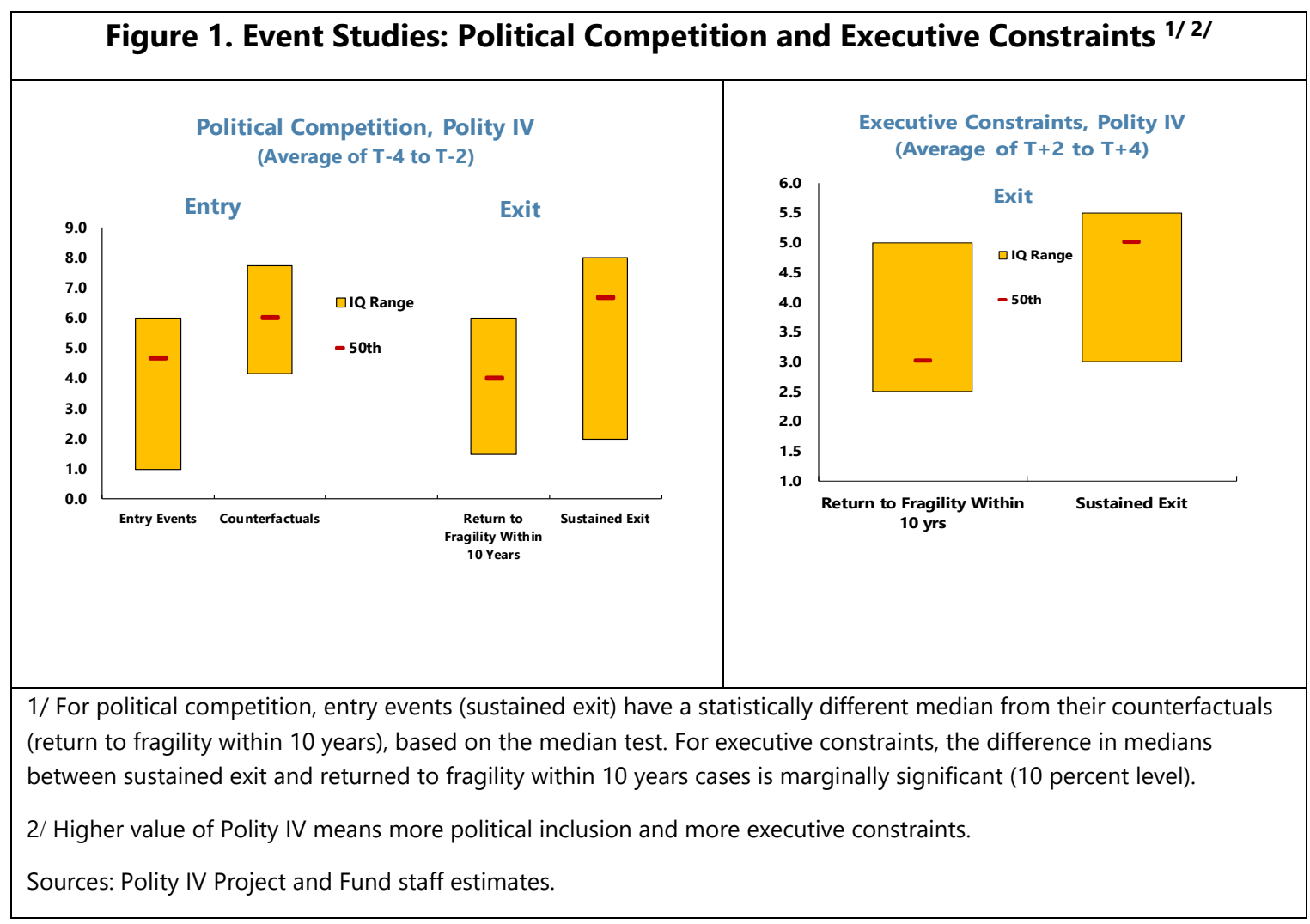

- The size of social spending (health/education) helps sustained exit from fragility (Figure 2). Both health and education spending are significant at one percent level by the median test. Also, countries with exit events had statistically stronger human development fundamentals as measured by Human Development Index (HDI) than their counterfactuals (Figure 2), based on the median test too. These findings may indicate that better social conditions could affect confidence in government, political support, and traction of reforms through promoting more inclusive growth, supporting a virtus cycle to exit from fragility and its sustainability. While these findings are based on simple event studies, they apper in line with the existing studies as well as other finding in the paper too. For example, IMF (2019) and Gelbard et al., (2015) emphasize the importance of social spending to keep macroeconomic, social and political stability in fragile states. ${ }^{26}$ Moreover, an increase in GDP growth could help to

\footnotetext{
${ }^{26}$ Social spending is a macro-critical issue in LICs because it poses risks to social and political stability (IMF, 2019). Thus, raising social spending could help to improve economic development and address political instability issues in fragile countries-both of which are key factors to help countries exit fragility. The creation of fiscal space for social spending is also a crucial factor that helped fragile states to build resilience (Gelbard et al., 2015).
} 
prevent countries from entering into fragility and raise the probability of exiting from fragility, as noted in the findings from the logit model (see Section IV-C).

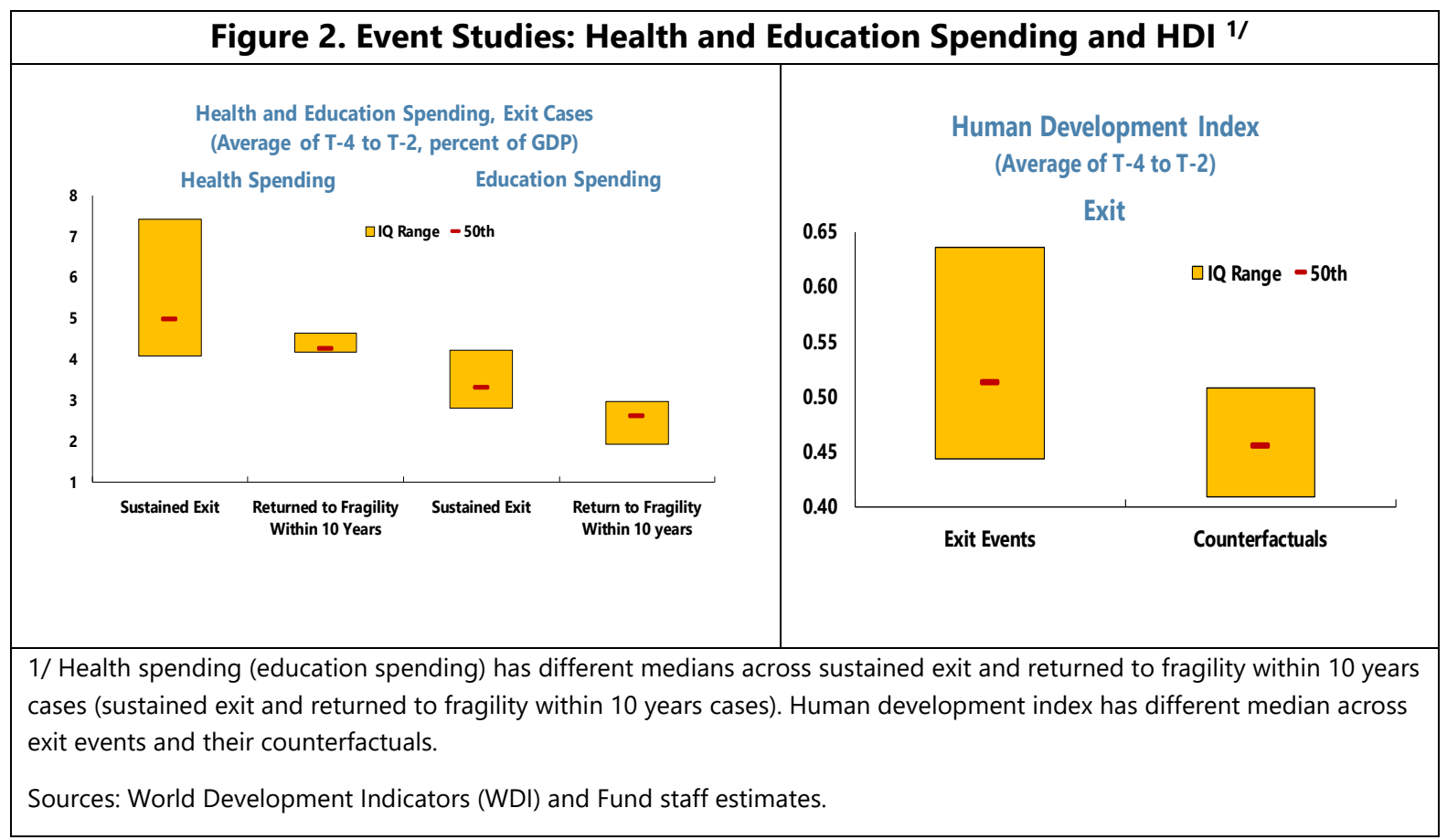

- Pivotal moments seem to be more associated with the cases of exit from fragility. The share of exit events with pivotal moments around the exit is higher than that in their counterfactuals (about 20 percent vs. 10 percent, statistically significant at 1 percent level). ${ }^{27}$ This holds for sustained exit as well as early exit from fragility (about 25 percent vs. 5 percent, and about 25 percent vs. 10 percent, statistically significant at 1 percent level). ${ }^{28}$ These observations are in line with the discussions in Collier (2020).

- Conflict may have lasting effect on the likelihood of exiting from fragility. The share of the cases with conflict in the identified exit events is statistically smaller than that of their counterfactuals (30 percent vs. 40 percent, statistically significant at 5 percent). ${ }^{29}$ This seems to be in line with other studies that highlighted that the legacy of conflict has made it difficult for fragile states to escape from fragility (Gupta et al., 2005; Cillers and Sisk, 2013; Hegre et al., 2017).

\footnotetext{
27 The "pivotal moments" group had the moments between T-2 and T+2.

${ }^{28}$ The result holds for exit and its sustainability even after dropping the cases and counterfactuals with conflicts from the sample.

${ }^{29}$ In case there are conflicts between T-1 and T-5. But we got the same results (i.e., statistically significant at 5 percent) when the period is extended to $\mathrm{T}-1$ to $\mathrm{T}-10$.
} 
- We did a couple of robustness check on some of the above findings. Due to limited data availability for some indicators, especially social spending in percent of overall government spending, the available sample is too small to apply the median test. However, many of the findings seem to survive after the robustness checks.

$>$ "Policy efforts" to preserve social spending may affect early exit from fragility. In the above, we use social spending in percent of GDP. However, in general, LICs face tight financing constraints and reprioritize their spending to create space for social spending. This is particularly relevant when they are at the brink of falling into fragility or in state fragility. This suggests policy efforts to protect social spending could be better measured by social spending in percent of overall fiscal spending instead of in percent of GDP, as in Besley and Persson (2010). While the small numbers of sample do not allow for the application of statistical tests, Figure 3 seems to indicate preserving health spending could help early exit from state fragility.

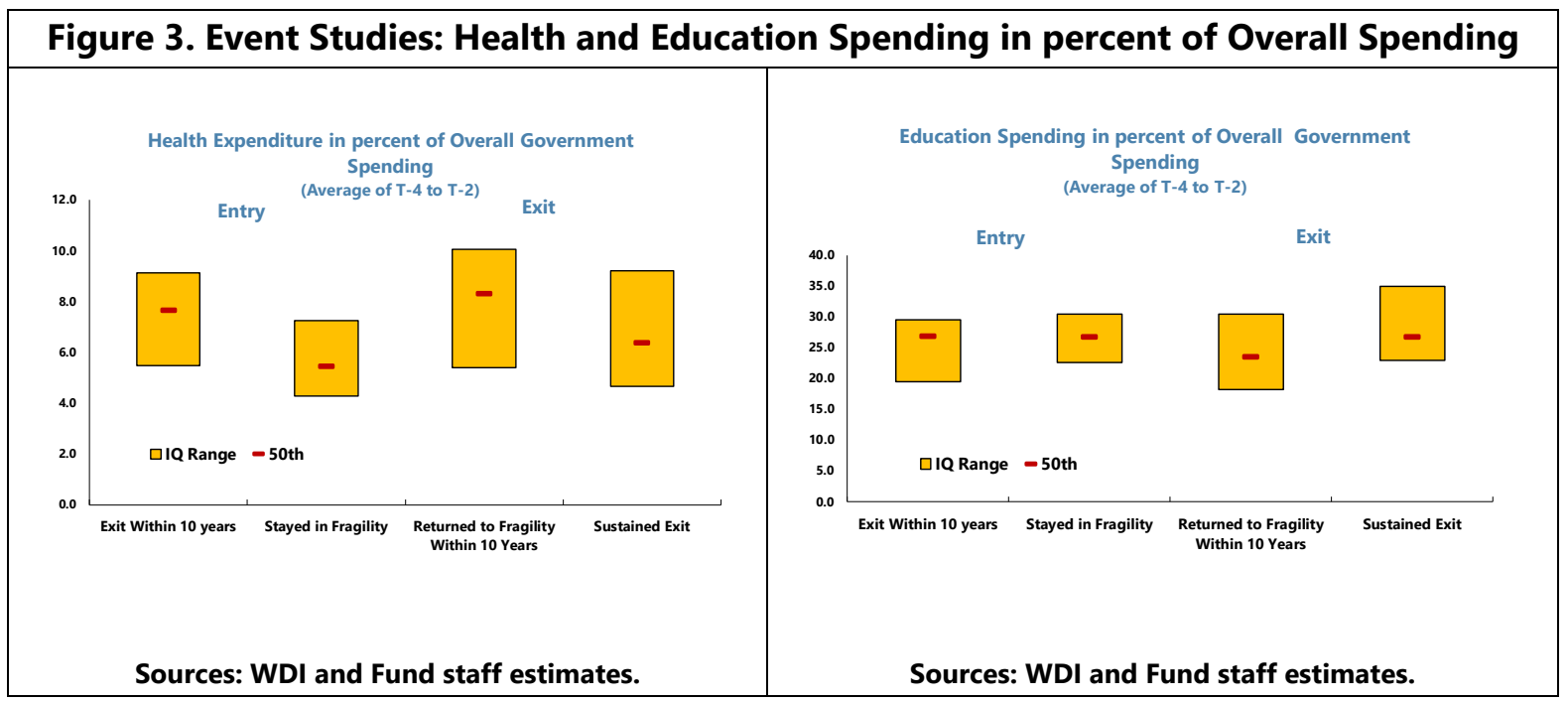

$>$ Dropping conflict episodes do not appear to affect many of the above results. The definition of state fragility includes both slow moving factors (e.g., institutions, proxied by CPIA) and fast moving factors (conflicts). Therefore, it would be interesting to check whether the above results hold after stripping out the identified entry/exit cases with conflicts. ${ }^{30}$ Even after dropping the identified turning points with conflicts, (i) political competition affects falling into fragility (i.e., the medians of the entry events without conflicts and the counterfactuals are statistically different at one percent level), and (ii) HDI affects exit from fragility (statistically significant at one percent level). On the other hand, the differences in the medians of health and education spending (in percent of GDP) between exit events returning to fragility and sustained exit cases become smaller after

\footnotetext{
${ }^{30}$ We set conflict cases: (i) between $\mathrm{T}-2$ and $\mathrm{T}+2$ for entry cases; and (ii) after $\mathrm{T}$ for exit cases. The latter intends to drop cases that returned to fragility due to conflicts.
} 
dropping the conflict cases. Unfortunately, however, the small sample hampers applying the statistical methodology. Therefore, at this stage, it is difficult to get concrete results for social spending.

\section{B. Synthetic Control Method (SCM)}

\section{Next, we will apply the SCM to look for systematic differences in the behavior of indicators across identified entry/exit events and their counterfactuals. The SCM is a data-driven} procedure for comparing the performance of an indicator in one country against a control group with structured guidelines for the selection of the control group and weights to compute a synthetic projection (Abadie et al., 2010). ${ }^{31}$ The method demonstrates the counterfactual effect of a trigger event (or policy intervention) by estimating what the outcome variable would have been in the absence of a trigger event (or policy intervention). Therefore, relative to simple event studies that put the same weight across samples, the SCM provides a safeguard against extrapolation and uses weighted average of the selected control groups.

This paper focuses on investigating any meaningful difference in economic activity, measured by real GDP per capita, between the identified events and their counterfactuals. The SCM requires relatively long time series for its application, and this considerably limits the range of indicators to which the SCM can be applied in this study. Therefore, the paper focuses on the level of GDP per capita, as a proxy of overall economic activity. ${ }^{32}$ The estimated synthetic projection describes a counterfactual that could have materialized if a country had not entered or exited from fragility. A control group consists of the counterfactuals identified in Section IV and those derived from a probability model that follows Gelbard et al. (2015). Therefore, a control group for entry into fragility includes countries that were likely to enter but did not enter fragility. Likewise, for a control group for exiting fragility, we selected cases that were likely to exit but did not exit from fragility.

The synthetic projections suggest significant costs of entering into and staying in fragility. The left-hand chart in Figure 4 plots median and quartile band of the "gap" between actual real GDP per capita and that derived from the SCM (i.e., the control group) at 3 and 7 years after

\footnotetext{
31 The SCM makes the relative contribution of each control group to the counterfactual explicit, with weights restricted to be positive and sum to one. We selected countries in the control group for an entry (exit) event that are not (are) in fragility but with high (low) implied probability of fragility estimated by a logit model that is commonly used to detect the conditional probability of fragility in the literature. Weights are selected based on optimization over the sample prior to the trigger event to mimic the behavior of the target as much as possible. This feature should help the SCM account for country characteristics that are omitted by event studies.

32 Among the panel of countries selected, GDP per capita remain the only indicator of economic activity with long-enough series to estimates synthetic series. This has also been solely used in the empirical literature on the economic cost of fragility (Novta and Pugacheva, 2020; Ncube et al., 2014).
} 
entering into fragility. ${ }^{33}$ We further divide the group into two subgroups: staying in fragility and early exit groups. The left-hand chart shows that early exit cases tend to have better real GDP per capita gap than cases that stayed in fragility and indicates two interesting observations.

- Cost of staying in fragility. Our analysis shows that the median gap of per capita GDP between countries staying in fragility and the control group (non-fragile cases)-interpreted as cost of staying in fragility-is about - $12(-24)$ percentage points after 3 (7) years, with a quartile band $[-4,-23]$ percentage points $\left([-11,-36]\right.$ percentage points after 7 years). ${ }^{34}$ This is in line with the finding that the economic costs of fragility have been capitalized to much lower average growth rates over time (World Bank 2018; Mueller and Tobias 2016). Also, the estimated magnitude is comparable to existing literature on macroeconomic cost of fragility and conflicts (e.g., Novta \& Pugacheva, 2020; Mueller, 2013; Ncube et al., 2014). ${ }^{35}$

- Benefit of early exit. The median deviation for countries that remained in fragility 3 years after entering stands at about 8 percentage points of lower GDP per capita (i.e., the difference between "Early exit" and "Stay FS" at T+3 in the left hand chart in Figure 4) compared to those that exited early. The difference increases to about 12 percentage points 7 years after entering fragility. The difference is statistically significant at 10 percent level for year $T+3$ and 5 percent for $T+7$ by the Mood median test, suggesting the substantial benefit of early exit.

\footnotetext{
33 In Figure 4, a negative gap means that actual real GDP per capita is lower than that implied by the SCM (or counterfactuals). Year ( $T$ ) is the year when countries entered or exited from fragility. Based on available data, there are 37 entry cases investigated. The sample is further divided into early exit (15 countries) and staying in fragility (22 countries).

${ }^{34}$ In addition, the 90 percentile points are around zero in both $T+3$ and $T+7$.

35 For example, Novta and Pugacheva (2020) estimated about 20 (30) percent GDP cost of staying in fragility after 3 (7) years, where the "cost" is measured by the difference between the implied response of GDP against conflict by the local projection model (when controlling for the forecast before the conflict started, the estimated impact is 10-15 percent after 3 years and [.] percent after 5 years). Ncube et al. (2014) estimate the growth difference between fragile countries and non-fragile countries is about 5 percent per year, suggesting 15 percentage points (35 percentage points) difference after 3 (7) years. Mueller (2013) estimated cost of a civil war: about 16 (19) percent GDP cost after 3 (7) years, where cost is measured as the growth in GDP per capita. These estimates are inside the quartile bands of our estimate of the cost of staying in fragility.
} 


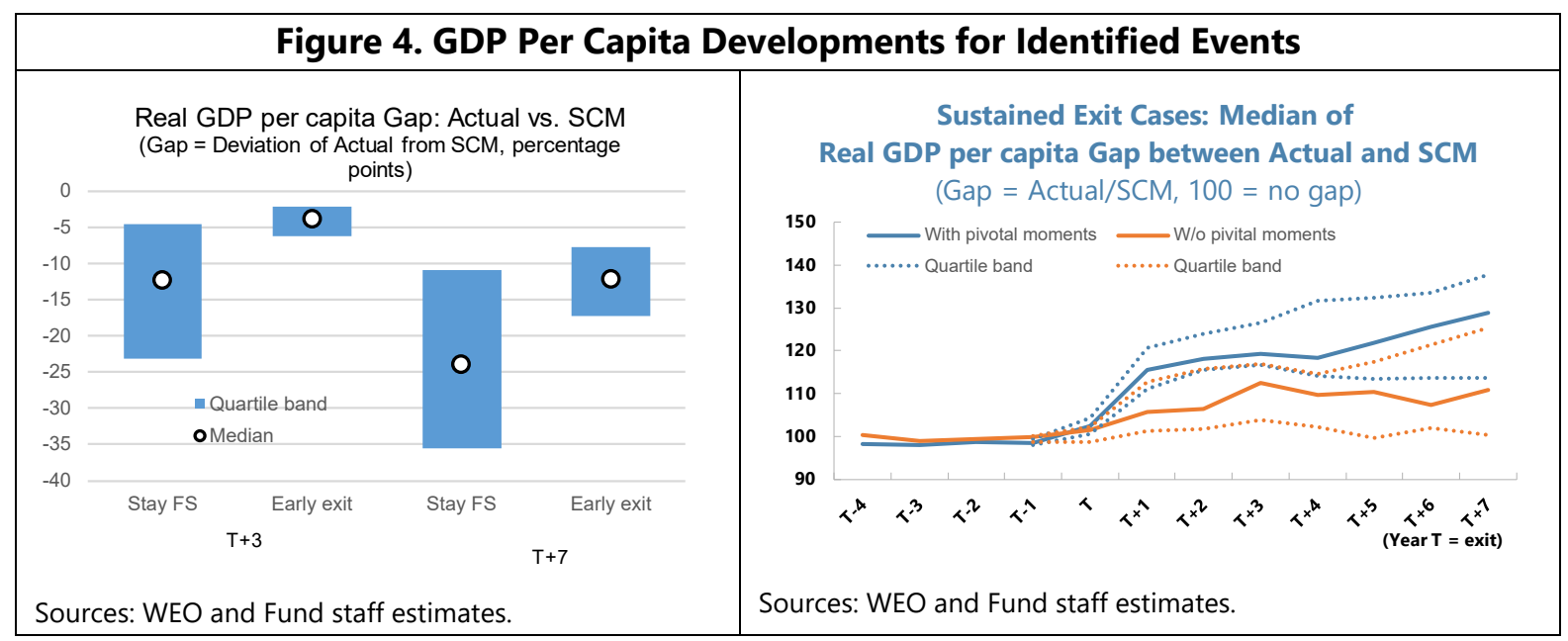

\section{For the cases of sustained exit, "pivotal moments" appear closely associated with stronger economic activity relative to the control group, supported by improved policy and institutions. ${ }^{36}$}

- In the right hand chart in Figure 4, real GDP per capita in countries with pivotal moments around the exit rises strongly for the sustained exit cases, more strongly than for those without pivotal moments. The average median deviation for sustained exit countries with pivotal moments is about 9 (11) percentage points on average during the first 4 (7) years relative to the countries without pivotal moments. ${ }^{37}$ The differences are statistically significant (at 5 percent level).

- Interestingly, the sustained exit cases with pivotal moments have systematically higher CPIA scores $_{L}$ as a possible proxy for the quality of a country's present policy and institutional framework, than those without the moments (at 10 percent significant level by the median test) after the exit, while the cases with pivotal moments have systematically lower CPIA scores than cases without the moments before the exit (at 5 percent level). ${ }^{38}$ This observation seems consistent with the discussion in Collier (2019) and IGC (2018): some countries have grabbed the chance of "pivotal moments" to implement critical reforms that facilitated

\footnotetext{
36 There are 24 sustained exit cases. The paper does not discuss the case of returning to fragility after exit ( 9 cases, most of which actually returned to fragility on average within 7 years of exit), because the data do not show a clear story, perhaps reflecting that the economic activity data are contaminated by different timing of falling back to fragility.

37 The "pivotal moments" group had the moments during T-2 and T+2. There are only a few sustained exits with pivotal moments consisting of only economic crisis (i.e., more pivotal moments with changes in executives), suggesting the result is not likely to reflect the base effect of a collapse of output during the economic crises.

38 For example, Bolivia, Grenada, Zambia and Guyana (with pivotal moments identified by the SCM as change in government or transition to a more transparent democracy) demonstrated notable improvemet in CPIA scores by about 2.4 (2.4 at T-2), 1.6 (2.7), 1.25 (2.85) and 1.2 (3.3) points estimates respectively between T-1 and T+3, while those without pivotal moments did not show notable changes in the CPIA scores during the same period.
} 
successful exit from fragility with sustainable growth. During "pivotal moments," policy makers have an opportunity to change the expectations of their citizens for the better, which would strengthen the traction of government policies as well as societal support to the state's institutions, which in turn strengthens their effectiveness.

In sum, the above analysis indicates a possible nexus of growth/resilience of an economy and quality of institution/effectiveness of government, especially the cases of sustained exit from fragility. This issue will be further investigated in the next subsection by employing a logit model.

\section{Logit Model}

The third empirical approach applies a logit model to ascertain the importance of the various factors influencing turning points of state fragility. In line with existing literature of empirical studies on the determinants of fragility, using a logit model is motivated by the fact that entry or exit from fragility is a binary variable. Also, the logit model is by its construction non-linear-the first derivative of a specific regressor (i.e., its coefficient in a linear regression) depends on other regressors, suggesting that the logit model already implicitly captures any interaction between regressors. However, different from typical panel regressions on the determinants of fragility, this paper, focusing on turning points of fragility, does not use panel data for a large number of countries. Instead, our sample includes identified events and their counterfactuals without a time dimension. Therefore, the analysis in this subsection aims to illuminate the influence of factors that affect turning points at the moment of entering/exiting from fragility.

We investigate both fast-moving factors (e.g. GDP per capita growth, government expenditure per capita, etc.) and slow moving factors (e.g., executive constraints, government effectiveness, etc.) as possible factors contributing to the turning points. ${ }^{39}$ Let us assume that:

$$
y_{i}=x_{i}^{\prime} \beta+\xi_{i}
$$

\footnotetext{
39 There are other important factors such as social and political dimensions or developments in neighboring countries that may affect the turning point of fragility. But due to lack of data, we are not controlling for all of these factors. However, these factors are often correlated with the variables we are controlling for (e.g., governance) and thus the specification of the paper is to some extent able to control for these factors. For example, in our sample, government effectiveness (as a proxy for governance) is highly correlated to GDP per capita (correlation coefficient: 0.65 ), suggesting that to some extent the effect of initial condition to output growth (e.g., Starting from low output (very poor country) may require more sustained growth to exit fragility than starting from a higher output level) is controlled. While not reported, we also checked whether inequality (exit in neighborhood) can affect turning points (exit). The result is negative-no statistically significant impact.
} 
where $y_{i}$ is equal to 1 if country $i$ in a given year is entering or existing from fragility and 0 otherwise. The conditional probability of entering or exiting fragility given the influencing factors is $\operatorname{Pr}\left(y_{i}=1 \mid x_{i}, \beta\right)$, with $\beta$ representing the marginal effect of regressors on the conditional probability. Under the assumption that $\xi_{i}$ is an i.i.d. logistic distribution, the conditional probability can be written as:

$$
\operatorname{Pr}\left(y_{i}=1 \mid x_{i}\right)=\frac{1}{1+\exp \left(-x_{i}^{\prime} \beta\right)}
$$

Applying the maximum likelihood estimator (MLE) gives the estimate of the marginal effect of regressors on the conditional probability. Equation (2) will be separately estimated for the two samples: the one including entry events and their counterfactuals; and the other including the exit events and their counterfactuals. In order to reduce endogeneity, we use lagged values for explanatory variables.

\section{The very persistent nature of fragility poses big challenges to get a sufficiently large number of observations to estimate the logit model. Combining the identified entry events} with their counterfactuals gives 85 observations in the "entry" logit model and 69 observations in the "exit" logit model. This relatively small number of observations considerably limits the number of explanatory variables that could be included in the right hand side of equation (1). In particular, van der Ploeg et al. (2014) discusses that at least 20 observations per predictor are required to achieve good stability and high expected performance, and the estimated marginal effects are robust to sample size as long as the size meets this rule of thumb (Bergtold et al., 2017). As a result, we limit the number of explanatory variables in equation (1) to 3 or $4 .{ }^{40}$

\section{The most robust determinants of entry/exit event are real GDP per capita growth and} government effectiveness. ${ }^{41} 42$ Given the constraints on the number of regressors on the right hand side, we tried a number of combinations of indicators in equation (1) (see Appendix III). Since an intuitive interpretation of $\beta$ is not straightforward in the logit model, the paper shows the effects of the two most robust explanatory variables on the implied probability, instead of discussing the value of the estimated parameters. Figure 5 displays the implied probability of entry/exit, depending on the two most significant variables-government effectiveness and real GDP per capita growth, evaluated at different values of the explanatory indicator specified by the horizontal axis and at the mean for other regressors. In the left chart in Figure 5, with the values of indicators other than real GDP per capita growth set at their means, higher growth would

\footnotetext{
${ }^{40}$ Agresti (2007) recommends at least 10 observations for each predictor. In the paper, however, we will include at most four explanatory variables in the regressions to avoid multicollinearity.

${ }^{41}$ Real GDP per capita growth and government effectiveness are not correlated with each other (the correlation coefficient is only 0.08 ).

42 As many other empirical analyses, the empirical model used on this paper is not free from measurement errors. Such errors may create measurement bias. However, the bias could only lower (not increase) the robustness of the coefficients. Thus, such data quality issues would weaken the relevance of these findings.
} 
reduce the implied probability of entering into fragility: from nearly 100 percent probability when the growth is -5 percent to about 25 percent when the growth is 5 percent. The shadowed area shows the confidence interval at 95 percent level.

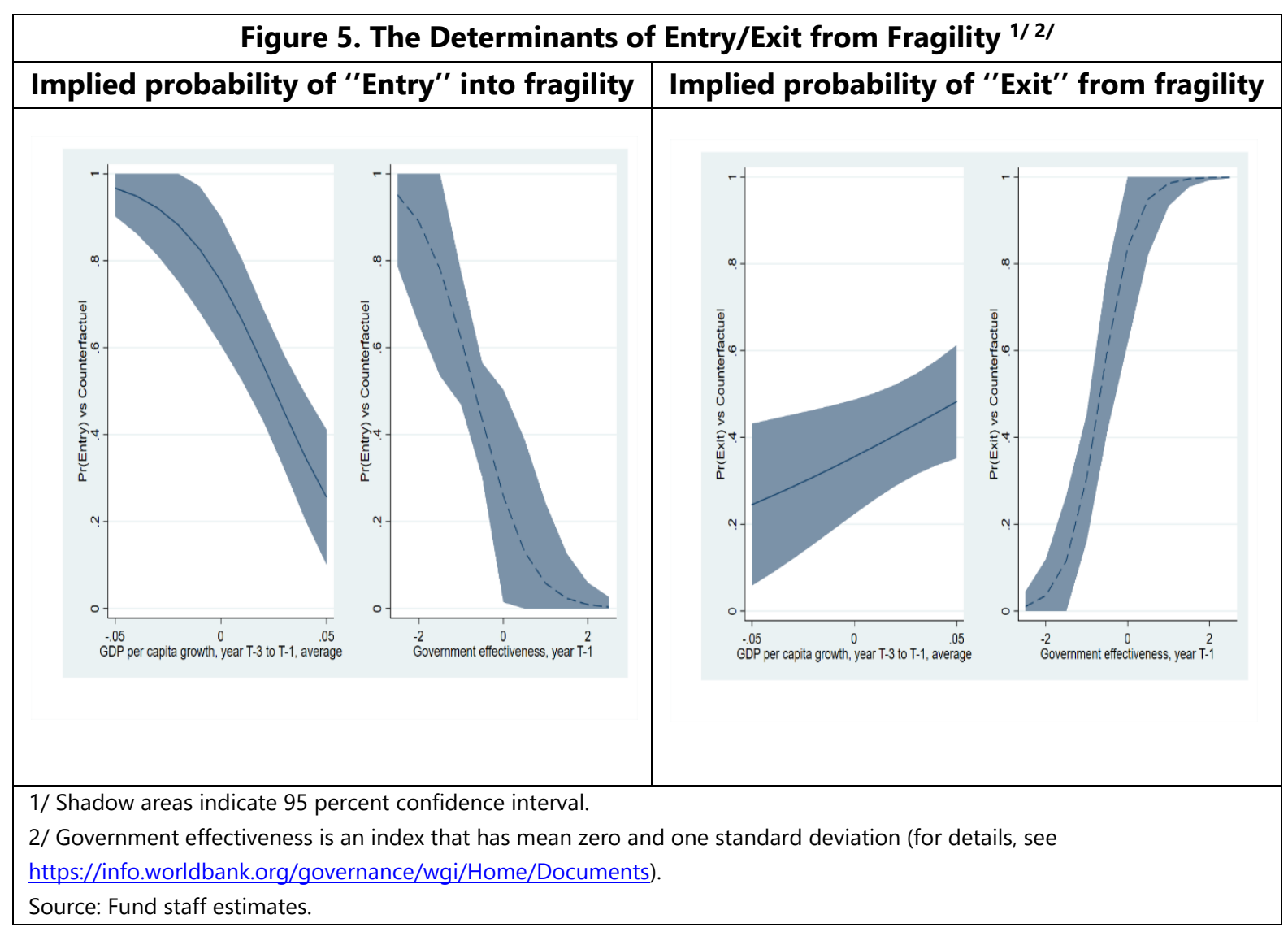

- Growth of real GDP per capita and government effectiveness affect the probability of entry or exit points. Higher (lower) real GDP per capita growth a proxy for "fast moving" fragilityinducing factors, is likely to reduce (raise) the likelihood of entries and raise (reduce) the likelihood of exits from fragility. Likewise, stronger (weaker) government effectiveness, a proxy for "slow moving" factors, is likely to reduce (raise) the likelihood of entry and raise (reduce) the likelihood of exit from fragility.

- $\quad$ There is an asymmetry in the implied impact of the two indicators on the conditional probability of entry or exit. Quantitatively, real GDP per capita growth seems to matter more for entry than for exit as reflected in the steeper slope of the implied probability of "entry" than that of "exit." In other words, the implied probability of entering fragility would change more than that of exiting from fragility for the same change in real GDP per capita growth (e.g., the implied probability of entry declines by 75 percentage points by raising growth from -5 percent to 5 percent, while that would increase the probability of exiting from fragility by only 20 percentage points). For government effectiveness, the effect on the 
probabilities of entry or exit is more symmetric, but likely to be non-linear, or depending on initial conditions, as implied by a "hot" zone where the slope of the schedule of the implied probability is pretty steep relative to that in other areas (e.g., somewhere like domain [-1.5, $1]$ ). This suggests more benefits of improving government effectiveness when countries have already obtained some level of government effectiveness.

\section{There is another interesting asymmetry in the impact of growth and government} effectiveness on the conditional probability of entry or exit. To investigate this, let's plot a change in the conditional probability schedule when growth declines or government effectiveness improves, while keeping other explanatory variables unchanged at their means. The span of the variation ( 2 percentage points for growth and 0.25 points for government effectiveness) is selected because it is close to the change from the median to the $25^{\text {th }}$ percentile for growth and the median to the $75^{\text {th }}$ percentile for government effectiveness in the samples used for the logit model. The vertical axis shows a change in the implied probability $(0.25$ indicates 25 percentage points) when government effectiveness (per capital growth) changes, given a specific value of per capita growth (government effectiveness).

- A decline in growth has asymmetric size of impact on the implied probability of entry or exit from fragility. Lowering growth raises (reduces) the probability of entering (exiting from) fragility, given the level of government effectiveness (the left hand chart in Figure 6). But the impact of growth is much larger for "entry" cases than "exit case." Moreover, there is a "hot zone" for a change in the conditional probability of entering fragility, within some range of government effectiveness $[-1,0.5] .{ }^{43}$ This may suggest the importance of maintaining growth (or maintaining short-term stability and avoiding an output collapse) to avoid falling into fragility. This benefit seems particularly large for countries in the mid-range of government effectiveness, or development of institutions.

- On the other hand, improving government effectiveness has more uniform effect on the implied probability than growth, with more powerful effect on the probability of exit. Improving government effectiveness will shift the probability conditional on growth in a favorable direction - a lower probability of entry and a higher probability of exit (the right chart in Figure 6). However, different from the impact of growth, its effect seems more uniform (i.e., with gentler slope of the "bell" curve, or no "hot zone") and matters more for "exit" cases.

${ }^{43} 67$ percent of countries in the sample is included in this range. 


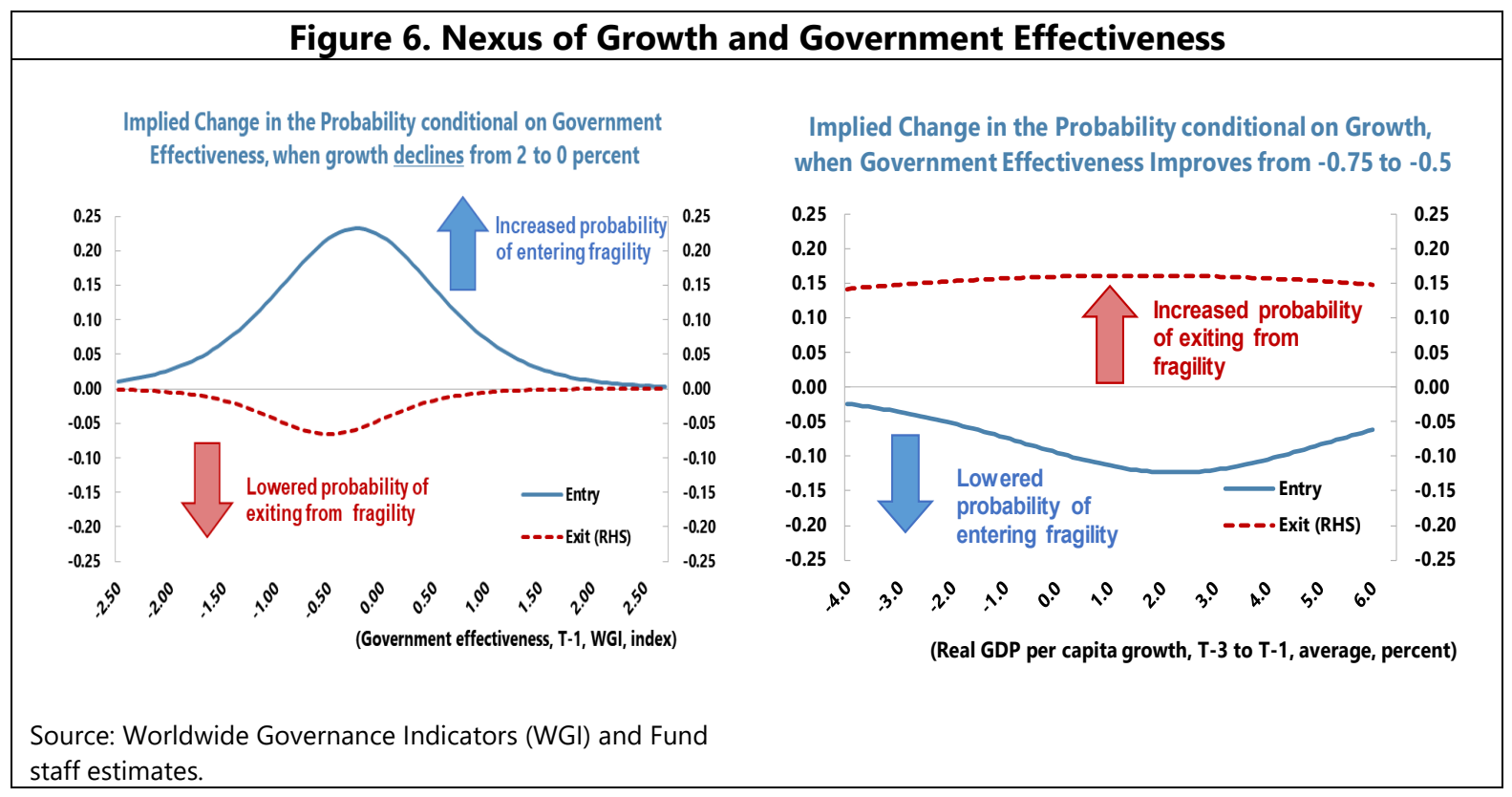

The above observations would suggest differential effects of growth (a proxy for fastmoving factors) and government effectiveness (a proxy for slow-moving factors) on the likelihood of entering or exiting fragility. Avoiding a growth collapse should help a country both avoid turning into and exiting from fragility. But it helps more a country at the brink of falling into fragility, especially a country with some level/quality of institution. On the other hand, improving government effectiveness would raise the probability of exit and make it more robust to shocks to growth, but not so much help avoid falling into fragility, especially when adverse growth shocks cause an economic contraction. In sum, there are two implications. The first is that preventing a growth collapse by timely and appropriate counter-cyclical policies is critical to prevent a country from falling into fragility, while strengthening government effectiveness/institutions seems the main factor for a successful exit from fragility. The second is, however, that the effectiveness of maintaining growth to avoid entering into fragility depends on the initial level/quality/effectiveness of government institutions. For a country with very weak institutions (less than -1), the benefits of avoiding a collapse of growth diminish substantiallyone could even imagine a situation where aggressive macroeconomic policies to avoid a collapse of economic activity amidst weak government effectiveness result in macroeconomic and financial instability.

\section{Policy IMPlications ANd Conclusions}

This study empirically investigates factors determining when countries become fragile and when they get out of fragility. Given high persistence of state fragility, or a "fragility trap," deepening our understanding on these turning points-entry into and exit from persistent fragility-is important. The "fragility trap" is entrenched by the reinforcing interactions between 
economic and political instability, poor governance, weak institutional capacity, and lack of political and social inclusion. Therefore, there is no single silver bullet that can solely and completely cure the persistence of state fragility. This is particularly relevant now as the COVID19 crisis has pushed many countries to the brink of fragility and countries already in fragility are facing even higher barriers to exit than usual.

\section{Our three empirical approaches shed some new light on the turning points of fragility.} High persistence of state fragility poses a big challenge for the empirical investigation of entry into or exit from fragility, due to relatively small samples. To overcome this, we first identified plausible counterfactuals of entry and exit events, and then applied three different methodologies:

- First, the event studies highlighted the importance of political inclusion to avoid falling into fragility as well as exiting from it, and of social inclusion (protecting social spending) for an early exit as well as a sustainable exit from fragility. Also, "pivotal moments" around exits from fragility seem to facilitate exits and their sustainability.

- Second, applying the synthetic control method confirmed: (i) a substantial output cost of falling into and staying in fragility; (ii) a substantial benefit of early exit from fragility, compare to staying in fragility; (iii) "pivotal moments" around exits from fragility make these exits both sustainable and successful in terms of strong economic activity; and (iv) "pivotal moments" drive strong improvements in the quality of policies and institutional framework .

- Third, the estimated logit models show that real GDP per capita growth and government effectiveness matter for the probability of entry/exit from fragility. Moreover, there appear to be some asymmetries in the effect of the two factors. Growth has a bigger effect on preventing a country from falling into fragility than supporting exit (e.g., among near fragile countries, the probability of entering fragility would be about 40 percentage points higher, if real GDP per capita growth should decline from +2.5 percent to -2.5 percent). However, preventing economic contraction only helps when some basic level of government effectiveness already exists.

\section{The findings from a case study of two countries (Appendix VIII) that have demonstrated sustained exit from fragility are consistent with the above results. The study highlights the} importance of the sustained efforts: to improve institutions with political commitment, accountability, and reform ownership after political stability/peace was regained, supported by technical assistance from the international community; to maintain prudent macroeconomic policies to build resilience; and to secure spending, mainly through mobilizing domestic revenues, to improve social inclusion.

These findings suggest the following policy implications for developing countries in fragility or at the brink of fragility. 
First, countries at the brink of fragility should adopt-and be helped to adopt-timely and appropriate counter-cyclical policies to support economic activity. This has a critical policy implication for near-fragile countries in view of the significant growth impact of the COVID-19 shock. Specifically;

- When these countries are hit by adverse growth shocks, utmost policy efforts and international support are needed to prevent a sharp output contraction. In these countries, enhanced fiscal stimulus would be needed to help prevent a country from falling into a "fragility trap", though the effect of fiscal stimulus would be significantly weakened in countries with very weak government effectiveness. Also, countries at the brink of fragility face severe financing constraints, despite much needed fiscal spending to stimulate growth and social support. The international community, therefore, can support them financially, subject to appropriate governance safeguards and well-designed policies. ${ }^{44}$ This strategy is particularly effective when they are with some level/quality of institution (see the last paragraph in Section V). At the same time, the recipient countries should step up efforts for enhancing the effectiveness of their spending, while minimizing the associated fiscal risks, including those related to governance and corruption, through building institutions. ${ }^{45}$

- In good times, or when the post-COVID-19 recovery gets going, these countries (near-fragile and fragile) should build and maintain adequate external and fiscal buffers through prudent policies. While the importance of rebuilding macroeconomic policy buffers is reiterated in many occasions, this paper's finding adds another critical underpinning. A country with more buffers is less likely to face severe external pressures and more likely to have room for counter-cyclical macroeconomic policies against exogenous shocks. Thus, securing policy buffers could substantially lower the risk of experiencing a growth collapse, highlighting the importance of stability-oriented policies before a country is close to fragility.

\section{Second, improving institutions and enhancing political and social inclusion would be important to facilitate exit from fragility and make it sustainable. The observed correlation} of political inclusion, social spending, and better institutions with the identified turning points and sustainability of exit implies the possibility for a virtuous cycle that should help a country escape from fragility and its exit more sustainable, as indicated in the literature (e.g., IGC, 2018; Collier, 2020). Fiscal policy and fiscal capacity building could support the cycle. For instance, protecting social spending (health and education) should support enhancing political and social inclusion. The enhanced inclusion, if it goes together with good policies, should foster economic

\footnotetext{
44 In general, given elevated risks of debt distress in many low income countries, financing instruments should be selected not to hurt debt vulnerabilities of recipient countries.

45 For example, IMF (2018) discusses that measures to address governance and corruption weaknesses should be established as conditions for the use of IMF resources if they are of critical importance for achieving the goals of the member's program.
} 
stability and growth, enhancing the resilience of an economy (Gelbard et al., 2015). On the other hand, complementarities in state capacity (between fiscal and legal capacity) suggest the importance of fiscal capacity building (revenue as well as PFM) for enhancing institutions in general (see, e.g., Besley and Persson, 2010; 2011a). Better economic outcomes and capacity, supported by appropriate reforms and policies, would increase tax capacity, which could support state building, improve institutional capacity, and foster economic and human development further (e.g., Besley and Persson, 2010; Gaspar et al., 2016a, 2016b; and Akanbi, 2019). Exiting from fragility/avoiding falling into fragility should have substantial economic benefits, as highlighted by the SCM, that could be used for further institution, human capital and infrastructure building.

\section{Third, grabbing the chance of "pivotal moments" to embrace a new approach could make} the exit from fragility trap more sustainable and robust. Pivotal moments work by creating opportunities for leaders to take actions that signal new intentions, reset citizen expectations, and build trust (IGC, 2018). The event study shows "pivotal moments" are likely to facilitate exit and its sustainability. In addition, the further analysis based on the SCM highlights better economic outcomes in sustainable exit cases with pivotal moments around the exit, associated with improvements in the quality of policy and institution. A government that is willing to face the reality that past policies have failed is more likely to embrace a new, successful approach that will foster a sustainable exit from fragility. Given the importance of well-functioning institutions to escape from the fragility trap in a sustainable way (Section V-C), technical support can be particularly useful in the early post-recovery period to restart services and accelerate progress (Baser, 2011). IFIs could therefore seize the opportunity provided by pivotal moments to step up CD provision-provided that political commitment to sustain reform efforts and realize longlasting gains is in place (Akitoby et al., 2020). 


\section{REFERENCES}

Abadie, A., Diamond, A., and Hainmueller, J. 2010. Synthetic control methods for comparative case studies: estimating the effect of California's tobacco control program. Journal of the American Statistical Association, Vol. 105, No. 490, pp. 493-505.

Acemoglu, Daron and James Robinson, 2012, Why Nations Fail: The Origins of Power, Prosperity, and Poverty.

Acemoglu Daron and James A. Robinson, 2021, "Building Inclusive States: A Simple Framework," in Macroeconomic Policy in Fragile States, Edited by Ralph Chami, Raphael Espinoza, and Peter J. Montiel, Forthcoming Oxford University Press.

Ades, A. and Chua, H.B. 1997, "Thy Neighbor's Curse: Regional Instability and Economic Growth," Journal of Economic Growth, 2, pp. 279-304.

Agresti, A., 2007. An introduction to categorical data analysis, 2nd ed. Hoboken. NJ: John Wiley \& Sons, Inc.

Akanbi, Olusegun Ayodele, 2019, "State Institutions and Tax Capacity: An Empirical Investigation of Causality," IMF Working Paper No. 19/177, Washington, D.C.: International Monetary Fund.

Akitoby, Bernardin, Jiro Honda, Hiroaki Miyamoto, Keyra Primus, and Mouhamadou Sy, 2019, "Case Studies in Tax Revenue Mobilization in Low-Income Countries", IMF Working Paper No. 19/104, Washington, D.C.: International Monetary Fund.

Akitoby, Bernardin, Jiro Honda, and Keyra Primus, 2020, "Tax Revenues in Fragile and Conflict-Affected States-Why Are They Low and How Can We Raise Them?" IMF Working Paper No. 20/143, Washington, D.C.: International Monetary Fund.

Andrimihaja, Noro Aina, Matthias Cinyabuguma, and Shantayanan Devarajan, 2011, "Avoiding the Fragility Trap in Africa," The World Bank, Policy Research Working Paper 5884, Washington D.C.: The World Bank.

Baer, Katherine, Sanjeev Gupta, Mario Mansour, and Sailendra Pattanayak, 2021, "Building Fiscal Institutions in Fragile States-A Two-Step Approach," Book Chapter in Macroeconomic Policy in Fragile States (edited by Ralph Chami, Raphael Espinoza, and Peter J. Montiel).

Banks, Arthur S., and Kenneth Wilson A., 2019, Cross-National Time-Series Data Archive. Databanks International. Jerusalem, Israel.

Baser, Heather, 2011, "Special Report: Perspectives on Capacity Development in Fragile Situations." Retrieved at: https://www.oecd.org/dac/conflict-fragilityresilience/governance/docs/48311487.pdf 
Benedek, D., Gemayel, E., Senhadji, A., Tieman, A., 2021. "A Post-Pandemic Assessment of the Sustainable Development Goals," IMF Staff Discussion Note 21/xx (Forthcoming), International Monetary Fund, Washington, DC.

Bergtold, J. S., Yeager, E. A., and Featherstone, A. M. (2017). Inferences from logistic regression models in the presence of small samples, rare events, nonlinearity, and multicollinearity with observational data. Journal of Applied Statistics, pages 1-19.

Bertocchi, Graziella and Andrea Guerzoni, 2012, "Growth, history, or institutions: What Explains State Fragility in Sub-Saharan Africa?", Journal of Peace Research, Vol. 49, pp. 769-783.

Besley, Timothy and Torsten Persson, 2010, "State Capacity, Conflict, and Development," Econometrica, Vol. 78, pp. 1-34.

Besley, Timothy and Torsten Persson, 2011a, "Fragile States and Development Policy," Journal of the European Economic Association, Vol. 9, pp. 371-398.

Besley, Timothy and Torsten Persson, 2011b, Pillars of Prosperity: The Political Economics of Development Clusters, Princeton University Press.

Burnside, Craig and David Dollar, 2000, "Aid, Policies, and Growth," American Economic Review, Vol. 90, No. 4, pp. 847-868.

Carment, David, Yiagadeesen Samy, and Stewart Prest, 2008, State Fragility and Implications for Aid Allocation: An Empirical Analysis," Conflict Management and Peace Science, Vol. 25, pp.349-373.

Carment, David, Stewart Prest, Yiagadeesen Samy, 2011, "The Causes and Measurement of State Fragility," Fragile States: Causes, Costs, and Responses, Oxford Scholarship Online.

Cilliers, Jakkie, and Timothy D. Sisk, 2013, "Assessing Long-term State Fragility in Africa: Prospects for 26 'More Fragile' Countries." ISS Monograph No. 188, Institute for Security Studies.

Collier, Paul, 2007, "The Bottom Billion: Why the Poorest Countries are Failing and What can be Done About It", Oxford University Press, Oxford.

Collier, Paul, 2020, "Transition Programs: A Theory of the Scaffolding Needed to Build Out of Fragility" in Macroeconomic Policy in Fragile States, Edited by Ralph Chami, Raphael Espinoza, and Peter J. Montiel, Forthcoming Oxford University Press.

Commission on State Fragility, Growth and Development, 2018, "Escaping the Fragility Trap," Commission on LSE-Oxford Commission on State Fragility, Growth and Development.

De Groot, O.J. 2010, "The Spillover Effects of Conflicts on Economic Growth in Neighboring Countries in Africa," Defence and Peace Economics, 21, p.149-164. 
Deléchat, Corinne, Ejona Fuli, Dafina Glaser, Gustavo Ramirez, and Rui Xu, 2018, "Exiting From Fragility in sub-Saharan Africa: The Role of Fiscal Policies and Fiscal Institutions," South African Journal of Econometrics, Vol. 83, pp. 1-37

Dirienzo, C., and Das, J. 2017, "The Spillover Effects of Country Fragility in Africa," Developing Countries Studies, Vol.7, No.1, pp. 62-67.

Feeny, Simon, Alberto Posso, and Jonathan Regan-Beasley, 2015, "Handle with Care: Fragile States and the Determinants of Fragility," Applied Economics, Vol. 47, pp. 1073-1085.

Gaspar, Vitor, Laura Jaramillo, and Philippe Wingender, 2016a, "Political Institutions, State Building, and Tax Capacity: Crossing the Tipping Point," IMF Working Paper, WP/16/233, Washington, D.C.: International Monetary Fund.

Gaspar, Vitor, Laura Jaramillo, and Philippe Wingender, 2016b, "Tax Capacity and Growth: Is there a Tipping Point?", IMF Working Paper, WP/16/234, Washington, D.C.: International Monetary Fund.

Gupta, Sanjeev, Shamsuddin Tareq, Benedict Clements, Alex Segura-Ubiergo, Rina Bhattacharya, and Todd Mattina, 2005, "Rebuilding Fiscal Institutions in Postconflict Countries," IMF Occasional Paper No. 247, Washington, D.C.: International Monetary Fund.

Gelbard, Enrique, Corinne Deléchat, Ulrich Jacoby, Marco Pani, Mumtaz Hussain, Gustavo Ramirez, Rui Xu, Ejona Fuli, and Dafina Mulaj, 2015, "Building Resilience in Sub-Saharan Africa's Fragile States," African Department Paper, Washington, D.C.: International Monetary Fund.

Hegre, Håvard, Håvard Mokleiv Nygård, and Ranveig Flaten Ræder, 2017, "Evaluating the Scope and Intensity of the Conflict Trap: A Dynamic Simulation Approach," Journal of Peace Research, Vol. 54, pp. 243-261.

Independent Evaluation Office (IEO), 2018, "The IMF and Fragile States, Evaluation Report 2018," Independent Evaluation Office of the IMF, Washington, D.C.: International Monetary Fund.

International Growth Centre (IGC), 2018, Escaping the Fragility Trap.

International Monetary Fund, 2020, "Uganda: Request for Disbursement under the Rapid Credit Facility", IMF Country Report No. 20/165, Washington, D.C.: International Monetary Fund. ,2019, "A Strategy for IMF Engagement on Social Spending" IMF Policy Paper, Washington, D.C.: International Monetary Fund. ,2019, "Fiscal Monitor: Curbing Corruption" Fiscal Monitor, April 2019, Washington, D.C.: International Monetary Fund. 2019, "Uganda: Article IV Consultation", IMF Country Report No. 19/125, Washington, D.C.: International Monetary Fund. 
2017a, "Building Fiscal Capacity in Fragile Space," IMF Policy Paper, Washington, D.C.: International Monetary Fund.

2017b, "Building Fiscal Capacity in Fragile States-Case Studies", IMF Country Report No.

17/153, Washington, D.C.: International Monetary Fund.

2017, "Uganda: Article IV Consultation and Eight Review under the Policy Support Instrument", IMF Country Report No. 17/206, Washington, D.C.: International Monetary Fund.

,2015, "IMF Engagement with Countries in Post-Conflict and Fragile Situations-Stocktaking," Washington, D.C.: International Monetary Fund.

2013, "Uganda: 2013 Article IV Consultation and Sixth Review Under the Policy Support Instrument", IMF Country Report No. 13/215, Washington, D.C.: International Monetary Fund. 2012, "Staff Guidance Note on the Fund's Engagement with Countries in Fragile Situations," Washington, D.C.: International Monetary Fund.

,2011, "Macroeconomic and Operational Challenges in Countries in Fragile Situations," Washington, D.C.: International Monetary Fund.

2010, "Uganda: Seventh Review Under the Policy Support Instrument", IMF Country Report No. 10/132, Washington, D.C.: International Monetary Fund.

2008, "The Fund's Engagement in Fragile States and Post-Conflict Countries-A Review of Experience-Issues and Options", International Monetary Fund, Washington, D.C.: International Monetary Fund.

,2007, "Uganda: 2006 Article IV Consultation", IMF Country Report No. 07/29, Washington, D.C.: International Monetary Fund.

, 2002, "The Role of Capacity-Building in Poverty Reduction" IMF Issues Briefs, Washington, D.C.: International Monetary Fund.

Iqbal, Z., and Starr, H. 2008, "Bad Neighbors: Failed States and Their Consequences," Conflict Management and Peace Science, 25:315-331.

Kaplan, S., 2008, "Fragile States, Fractured Societies," Chapter 3 in Fixing Fragile States: A New Paradigm for Development, Praeger Security International, London. http://www.fragilestates.org/wpcontent/uploads/2012/01/FFS-Chapter-3-pp-35-46.pdf

Laeven, Luc and Fabian Valencia, 2018, "Systemic Banking Crises Revisited", IMF Working Paper No. 18/206, Washington, D.C.: International Monetary Fund. 
Ley, Eduardo and Florian Misch, 2014, "Output Data Revisions in Low-Income Countries", paper presented at conference Macroeconomic Challenges Facing Low-Income Countries.

Mueller, H., and Tobias, J. 2016. "The Cost of Violence: Estimating the Economic Impact of Conflict." Growth Brief, International Growth Centre, London.

Mueller, H. 2013. "The Economic Cost of Conflict." IGC Working Paper, International Growth Centre, London.

Ncube, M., Jones, B., and Bicaba, Z. 2014, "Estimating the Economic Cost of Fragility in Africa", AFDB Working Paper, WP/14/197, Tunisia.: African Development Bank.

Novta, N. and Pugacheva, E. 2020, "The Macroeconomic Cost of Conflict", IMF Working Paper, WP/20/110, Washington, D.C.: International Monetary Fund.

Redifer, Laure, Emre Alper, Neil Meads, Tunc Gursoy, Monique Newiak, and Alun Thomas, 2020, "The Development Path Less Traveled: The Experience of Rwanda", African Department Paper, Washington, D.C.: International Monetary Fund.

The Organization for Economic Co-operation and Development (OECD), 2015, States of Fragility 2015: Meeting Post-2015 Ambitions, OECD.

The World Bank, 2018, "Pathways for Peace: Inclusive Approaches to Preventing Voilent Conflict", World Bank Group, Washington, D.C.: The World Bank.

The World Bank, 2016, "World Bank Group Engagement in Situations of Fragility, Conflict, and Violence", World Bank Group, Washington, D.C.: The World Bank.

The World Bank, 2011, World Development Report 2011: Conflict, Security, and Development, The World Bank: Washington, DC.

Vallings, Claire and Magüi Moreno-Torres, 2005, "Drivers of Fragility: What Makes States Fragile?", Working Paper No. 7, Department for International Development, Poverty Reduction in Difficult Environments (PRDE).

van der Ploeg, T., Austin, P. C., and Steyerberg, E. W. (2014). Modern modelling techniques are data hungry: a simulation study for predicting dichotomous endpoints. BMC medical research methodology, 14(1):137.

Zoellick, Robert, 2008, "Fragile States: Securing Development," Survival, Vol. 50, pp. 67-84. 
Appendix I. Definitions of Fragile States in IFIs and Key International Actors ${ }^{47}$

\begin{tabular}{|c|c|}
\hline $\begin{array}{l}\text { African } \\
\text { Development } \\
\text { Bank }\end{array}$ & $\begin{array}{l}\text { Countries or situations with unique development challenges that have } \\
\text { resulted from fragility and conflict including weak institutional capacities } \\
\text { and poor governance, economic and geographic isolation, economic } \\
\text { disruption, social disruption and insecurity. }\end{array}$ \\
\hline $\begin{array}{l}\text { German Federal } \\
\text { Ministry for } \\
\text { Economic } \\
\text { Cooperation and } \\
\text { Development(BMZ) }\end{array}$ & $\begin{array}{l}\text { Fragile statehood exists in situations where there is low level of } \\
\text { government performance, where state institutions are weak or on the } \\
\text { verge of collapse and where the state either fails to perform core roles or } \\
\text { performs them wholly inadequately. The BMZ also refers to the CPIA } \\
\text { (compiled by the World Bank). }\end{array}$ \\
\hline $\begin{array}{l}\text { Country Indicators } \\
\text { for Foreign Policy }\end{array}$ & $\begin{array}{l}\text { Fragile states lack the functional authority to provide basic security within } \\
\text { their borders, the institutional capacity to provide basic social needs for } \\
\text { their populations, and/or the political legitimacy to effectively represent } \\
\text { their citizens at home or abroad. }\end{array}$ \\
\hline $\begin{array}{l}\text { Department for } \\
\text { International } \\
\text { Development } \\
\text { (DFID) }\end{array}$ & $\begin{array}{l}\text { DFID has used a broad definition ("Where the government cannot or will } \\
\text { not deliver core functions to the majority of its people, including the } \\
\text { poor.") but also refers to a combination of the three widely accepted } \\
\text { assessment frameworks: World Bank's CPIA-indicators, the Fund for } \\
\text { Peace's Failed States Index (FSI) and the Uppsala Conflict Database. }\end{array}$ \\
\hline European Union & $\begin{array}{l}\text { Fragility refers to weak or failing structures and to situations where the } \\
\text { social contract is broken due to the state's incapacity or unwillingness to } \\
\text { deal with its basic functions, meets its obligations and responsibilities } \\
\text { regarding service delivery, management of resources, rule of law, equitable } \\
\text { access to power, security and safety of the populace and protection and } \\
\text { promotion of citizens' rights and freedoms. }\end{array}$ \\
\hline G7+ & $\begin{array}{l}\text { [A] state of fragility can be understood as a period of time during } \\
\text { nationhood when sustainable socio-economic development requires } \\
\text { greater emphasis on complementary peacebuilding and State-building } \\
\text { activities such as building inclusive political settlements, security, justice, } \\
\text { jobs, good management of resources, and accountable and fair service } \\
\text { delivery. }\end{array}$ \\
\hline
\end{tabular}

${ }^{46}$ This table was prepared by FSDR/DEVINVEST, 2016. See https://www.ilo.org/wcmsp5/groups/public/--ed emp/documents/terminology/wcms 504528.pdf.

${ }^{47}$ This table was prepared by FSDR/DEVINVEST, 2016. See https://www.ilo.org/wcmsp5/groups/public/--ed emp/documents/terminology/wcms 504528.pdf. 


\begin{tabular}{|c|c|}
\hline $\begin{array}{l}\text { International } \\
\text { monetary Fund }\end{array}$ & $\begin{array}{l}\text { Fragile states have characteristics that substantially impair their economic } \\
\text { and social performance. These include weak governance, limited } \\
\text { administrative capacity, chronic humanitarian crises, persistent social } \\
\text { tensions, and often, violence or the legacy of armed conflict and civil war. } \\
\text { In these countries the poor quality of policies, institutions and governance } \\
\text { substantially impairs economic performance, the delivery of basic social } \\
\text { services and the efficacy of donor assistance. Such states are least likely to } \\
\text { achieve the MDGs. They also have considerable negative spillover effects } \\
\text { on economic growth in neighboring countries. }\end{array}$ \\
\hline $\begin{array}{l}\text { Organisation for } \\
\text { Economic Co- } \\
\text { operation and } \\
\text { Development } \\
\text { (OECD) }\end{array}$ & $\begin{array}{l}\text { Pockets of fragility may occur at a subnational level, making it hard to } \\
\text { keep the fragile states terminology. The States of fragility report } 2015 \\
\text { marks a change towards defining dimensions of fragility: violence, justice, } \\
\text { institutions, economic foundations and resilience. Thus, the OECD breaks } \\
\text { down the drivers of fragility for each country and reveals different patterns } \\
\text { of vulnerability instead of trying to stringently define fragility. }\end{array}$ \\
\hline $\begin{array}{l}\text { Swiss Agency } \\
\text { for } \\
\text { Development } \\
\text { and } \\
\text { Cooperation }\end{array}$ & $\begin{array}{l}\text { A state or context is describe as fragile if a significant proportion of the } \\
\text { population does not regard the state as the legitimate framework for the } \\
\text { exercise of power, if the state does not or cannot exercise its monopoly of } \\
\text { the legitimate use of force within its territory, and if the state is unable or } \\
\text { unwilling to provide basic goods and services to a significant part of the } \\
\text { population. }\end{array}$ \\
\hline $\begin{array}{l}\text { United States Agency } \\
\text { for International } \\
\text { Development } \\
\text { (USAID) }\end{array}$ & $\begin{array}{l}\text { Fragile states refer to a broad range of failing, failed, and recovering states } \\
\text { that are unable or unwilling to adequately assure the provision of security } \\
\text { and basic services to significant portion of their populations and where } \\
\text { the legitimacy of the governments is in question. USAID distinguishes } \\
\text { between fragile states that are vulnerable from those that are already in }\end{array}$ \\
\hline World Bank & $\begin{array}{l}\text { The World Bank defines fragile states according to their ranking in the } \\
\text { Country Policy and Institutional Assessment that includes a set of } 16 \\
\text { criteria grouped in four clusters: economic management, structural } \\
\text { policies, policies for social inclusion and equity, and public sector } \\
\text { management and institutions. The result is published every year in the } \\
\text { "Harmonized List of Fragile Situations". Fragile Situations include countries } \\
\text { or territories with (i) a harmonized CPIA country rating of } 3.2 \text { or less, } \\
\text { and/or (ii) the presence of a UN and/or regional peace- keeping or } \\
\text { political/peace-building mission during the last three years. }\end{array}$ \\
\hline
\end{tabular}




\section{Appendix II. Data Source}

Data Sources

\begin{tabular}{|c|c|c|}
\hline Indicator & Description & Source \\
\hline Change in effective executive & $\begin{array}{l}\text { Measures the number of times in a year that effective control of executive power } \\
\text { changes hands. Such a change requires that the new executive be independent of his } \\
\text { predecessor. This variable addresses one of drawbacks of the indicator related to major } \\
\text { government changes as some cabinet changes may not entail change in executive } \\
\text { power; }\end{array}$ & $\begin{array}{l}\text { Banks and Wilson } \\
\text { (2019)'s Cross National } \\
\text { Time Series Data } \\
\text { Archive }\end{array}$ \\
\hline Conflict & $\begin{array}{l}\text { Dummy variable. Number of casualties as a percent of the population in the previous } \\
\text { year. If a country falls in the top 25th percentile, then it is calssified as having conflict }\end{array}$ & $\begin{array}{l}\text { Uppsala Conflict } \\
\text { database }\end{array}$ \\
\hline CPIA & $\begin{array}{l}\text { The CPIA rates countries against a set of } 16 \text { criteria grouped in four clusters: (i) } \\
\text { economic management; (ii) structural policies; (iii) policies for social inclusion and } \\
\text { equity; and (iv) public sector management and institutions. The criteria are focused on } \\
\text { balancing the capture of the key factors that foster growth and poverty reduction, with } \\
\text { the need to avoid undue burden on the assessment process. }\end{array}$ & World Bank \\
\hline Education Expenditure (\% of GDP) & Total expenditure on educatoin as a share of GDP & WDI \\
\hline Executive constraints & $\begin{array}{l}\text { The extent of institutionalized constraints on the decisionmaking powers of chief } \\
\text { executives, whether individuals or collectivities. A seven-category scale is used, which } \\
\text { includes unlimited authority; slight to moderate limitation on executive authority; } \\
\text { substantial limitations on executive authority; executive parity or subordination. }\end{array}$ & Polity IV \\
\hline Financial Crisis & $\begin{array}{l}\text { Dummy variable. Takes the value of "one" when at least one of three crises occurs: } \\
\text { currency, banking, or sovereign debt }\end{array}$ & $\begin{array}{l}\text { Laeven and Valencia, } \\
2018\end{array}$ \\
\hline GDP per capita growth & Gross domestic product, current prices, national currency, percent change & WEO \\
\hline Government Effectiveness & $\begin{array}{l}\text { Government effectiveness captures perceptions of the quality of public services, the } \\
\text { quality of the civil service and the degree of its independence from political pressures, } \\
\text { the quality of policy formulation and implementation, and the credibility of the } \\
\text { government's commitment to such policies }\end{array}$ & $\begin{array}{l}\text { Worldwide Governance } \\
\text { Indicators }\end{array}$ \\
\hline Government expenditure ( $\%$ of GDP) & Total government expenditure as a share of GDP & WDI \\
\hline $\mathrm{HDI}$ & $\begin{array}{l}\text { An index of life expectancy, education, and per capita income indicators, which are } \\
\text { used to rank countries into four tiers of human development }\end{array}$ & United Nations \\
\hline Health Expenditure (\% of GDP) & Total expenditure on health as a share of GDP & WDI \\
\hline Infant Mortality & Number of death per 1000 live births & WDI \\
\hline Inflation & Consumer Prices, end of period, percent change (Percent, Units) & WEO \\
\hline Life expectancy & Life Expectancy at birth (in years) & WDI \\
\hline Military Expenditure (\% of GDP) & Total expenditure on military as a share of GDP & WDI \\
\hline Pivotal Moments (2 definitions) & $\begin{array}{l}\text { Pivotal moments---crises (have "one" when at least one of four crises occurs: currency, } \\
\text { banking, sovereign debt, and debt restructuring), and change in executive power. First, } \\
\text { create dummies. Then, plot three cases: crises, change in chief executives, and sum of } \\
\text { both. }\end{array}$ & Collier, 2020 \\
\hline Political Competition & $\begin{array}{l}\text { Political Competition combines two concepts, first, the degree of institiionalization or } \\
\text { regulation of political competition and second, the extent of government restriction on } \\
\text { political competition }\end{array}$ & Polity IV \\
\hline Political Stability & $\begin{array}{l}\text { Political Stability and Absence of Violence/Terrorism measures perceptions of the } \\
\text { likelihood of political instability and/or politicallymotivated violence, including terrorism }\end{array}$ & $\begin{array}{l}\text { Worldwide Governance } \\
\text { Indicators }\end{array}$ \\
\hline Regulatory Quality & $\begin{array}{l}\text { Regulatory quality captures perceptions of the ability of the government to formulate } \\
\text { and implement sound policies and regulations that permit and promote private sector } \\
\text { development }\end{array}$ & $\begin{array}{l}\text { Worldwide Governance } \\
\text { Indicators }\end{array}$ \\
\hline Tax Revenue as a percent of GDP & General government taxes, percent of fiscal year GDP (Percent of GDP, Units) & WEO \\
\hline Total Investment (Share of total spending) & Domestically financed capital expenditure as a share of total spending & WEO \\
\hline
\end{tabular}


Appendix III. Regression Tables:

Entry Events, by Logit Model

Dependent variable: Entry vs Counterfactual

GDP per capita growth, year T-3 to T-1, average

Government effectiveness, year T-1

Life expentance at birth, year T-1

Total Revenue as a \% of GDP

Inflation

Executive Constraints, year T-1

WEO: Terms of trade, goods, US Dollars, percent change (Percent, Units)

L\&V: Dummy that takes the value 1 if the country had

any kind of financial crisis.

Polity: Political Competition ; Political Competition

Constant

Observations

Standard errors in parentheses

*** $p<0.01, * * p<0.05, * p<0.1$

(1)

(2)

(3)

(4)

(5)

(6)

(7)

$-47.2975^{* * *}-42.6886^{* * *}-43.8960^{* * *}-39.4549^{* *}-38.7512^{* * *}-38.2088^{* * *}-38.4797^{* *}$

$\begin{array}{llllllll}(14.2282) & (13.3086) & (13.3384) & (15.9038) & (13.2831) & (13.2134) & (16.3812)\end{array}$

$\begin{array}{lllllll}-1.9832^{*} & -1.6427^{*} & -1.4550 & -1.6672 & -1.7839^{*} & -1.9712^{*} & -1.5852\end{array}$

$\begin{array}{lllllll}-1.9832^{*} & -1.6427^{*} & -1.4550 & -1.6672 & -1.7839^{*} & -1.9712^{*} & -1.5852 \\ (1.1207) & (0.9413) & (0.9646) & (1.1036) & (1.0237) & (1.0664) & (1.1120)\end{array}$

0.0375

$(0.0400)$

0.0055

(0.0231) -0.0215

-0.0215
$(0.0348)$

-130
-0.130
$(0.195)$

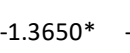

9634)

$-0.0278$

(0.0321)

$(0.0356)$

$\begin{array}{cc}-1.3014 & -1.8246^{* *} \\ (0.9242) & (0.9120)\end{array}$

$0.0342-0.0276$

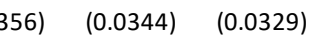

\begin{tabular}{|c|c|c|c|c|c|c|c|c|c|c|}
\hline \\
\hline & & -0.0215 & & & & & -0.0102 & & & \\
\hline & & (0.0348) & & & & & $(0.0302)$ & & & \\
\hline & & & -0.1302 & & & & & -0.0530 & & \\
\hline & & & (0.1951) & & & & & (0.1727) & & \\
\hline & & & & -0.0018 & & & & & -0.0059 & \\
\hline & & & & $(0.0132)$ & & & & & $(0.0122)$ & \\
\hline & & & & & 0.4664 & & & & & 0.6928 \\
\hline & & & & & (1.1650) & & & & & (1.1334) \\
\hline & & & & & & -0.0153 & & & & \\
\hline & & & & & & (0.1779) & & & & \\
\hline-2.4847 & -0.2051 & 0.2789 & -0.0164 & -0.3611 & -0.5841 & -0.4561 & 0.1647 & 0.2019 & 1.1063 & 0.2528 \\
\hline (2.8094) & $(0.9526)$ & (0.8738) & (1.4045) & (0.8218) & $(0.8926)$ & (1.5528) & (2.2436) & (2.5287) & (2.4383) & (2.3135) \\
\hline 67 & 67 & 68 & 53 & 61 & 63 & 52 & 69 & 55 & 62 & 65 \\
\hline
\end{tabular}

0.6928

1334)

$61-63$

52 
GDP per capita growth, year T-3 to T-1, average

Government effectiveness, year T-1

Life expentance at birth, year T-1

Total Revenue as a \% of GDP

Inflation

Executive Constraints, year T-1

WEO: Terms of trade, goods, US Dollars, percent change (Percent, Units)

L\&V: Dummy that takes the value 1 if the country had

any kind of financial crisis.

Polity: Political Competition ; Political Competition

Constant

Observations

Standard errors in parentheses

$* * * p<0.01, * * p<0.05, * p<0.1$
$-1.6562 *$

(0.9634)

$\begin{array}{lllll}-0.0375 & -0.0357 & -0.0361 & -0.0325 & -0.0401\end{array}$

(0.0372)

$\begin{array}{llll}(0.0298) & (0.0292) & (0.0275) & (0.0309)\end{array}$

\begin{tabular}{ccccccccccccc} 
& -0.0160 & -0.0394 & -0.0148 & -0.0228 & -0.0443 & 0.0002 & 0.0002 & & & \\
& $(0.0257)$ & $(0.0335)$ & $(0.0286)$ & $(0.0264)$ & $(0.0391)$ & $(0.0310)$ & $(0.0310)$ & & & \\
& 0.0083 & & & & 0.0323 & -0.0498 & -0.0498 & -0.0552 & -0.0552 & \\
& $(0.1491)$ & & & & $(0.1614)$ & $(0.1508)$ & $(0.1508)$ & $(0.1610)$ & $(0.1610)$ & \\
& & -0.0076 & & & -0.0381 & & & -0.0448 & -0.0448 & $-0.0483^{*}$ \\
& & $(0.0116)$ & & & $(0.0257)$ & & & $(0.0275)$ & $(0.0275)$ & $(0.0284)$ \\
& & & & & & & & & & \\
& & & -0.3749 & & & -1.1052 & -1.1052 & -1.0720 & -1.0720 & -1.1903 \\
& & & $(1.0359)$ & & & $(1.3046)$ & $(1.3046)$ & $(1.1825)$ & $(1.1825)$ & $(1.1912)$ \\
0.1014 & & & & 0.0906 & & & & & & 0.0693 \\
$(0.1534)$ & & & & $(0.1302)$ & & & & & & $(0.1350)$ \\
0.1138 & 1.7295 & 2.2160 & 1.8035 & 1.4847 & -0.3255 & -0.2794 & -0.2794 & -0.3281 & -0.3281 & -0.9792 \\
$(2.7340)$ & $(1.8424)$ & $(1.7556)$ & $(1.6770)$ & $(2.0613)$ & $(0.7063)$ & $(0.6544)$ & $(0.6544)$ & $(0.6991)$ & $(0.6991)$ & $(0.8629)$ \\
& & & & & & & & & & & & \\
54 & 67 & 73 & 76 & 66 & 62 & 66 & 66 & 61 & 61 & 61 \\
\hline
\end{tabular}




\section{Exit Events, by Logit Model}

Dependent variable: Exit counterfactua

(1)

(3)

(4)

(5)

(6)

(7)

(8)

(9)

(10)

(11)

GDP per capita growth, year T-3 to T-1, average

Government effectiveness, year T-1

Life expentance at birth, year T-1

Inflation

Executive Constraints, year T-1

WEO: Terms of trade, goods, US Dollars, percent change (Percent, Units)

L\&: Dummy that takes the value 1 if the country had any kind of financial crisis

Polity: Political Competition ; Political Competition

Constant

Standard errors in parentheses

$* * * p<0.01, * * p<0.05, * p<0.1$
13.1823* 13.5508* $15.9313 * 19.6929 * * 16.9690 * * 16.1826 *$ $\begin{array}{llllll}(7.1244) & (7.1947) & (8.9134) & (8.7387) & (8.6185) & (8.9142)\end{array}$

$2.6118^{* *} 2.6675^{* * *} 3.8820^{* * *} 3.3446^{* * *} 3.0562^{* * *} 3.4325^{* * *} \quad 2.3575^{* *} \quad 3.1956^{* *} \quad 2.8740^{* * *} \quad 2.6027^{* *} \quad 3.0018^{* *}$

$\begin{array}{lllllllllll}(1.0294) & (0.9313) & (1.4297) & (1.1734) & (1.1262) & (1.3085) & (0.9317) & (1.3020) & (1.0793) & (1.0573) & (1.2517)\end{array}$

$\begin{array}{llllllll}0.0050 & 0.0151 & 0.0480 & 0.0205 & 0.0339 & 0.0461\end{array}$

$\begin{array}{lllllll} & 0.0419) & (0.0419) & (0.0535) & (0.0448) & (0.0456) & (0.0512)\end{array}$

(0.0549)

$-0.3298$

(0.2840)

$-0.0351-0.0256$

$(0.0220)-(0.0185)$

$-0.1478$

(0.2170)

$\begin{array}{llllllllll}(3.0051) & (0.8631) & (1.9454) & (1.0061) & (0.9882) & (1.7580) & (2.9762) & (3.7116) & \text { (3.1556) } & \text { (3.1467) }\end{array}$

$59 \quad 59$

40

53

50

41

59

40

53

50

41




\section{Dependent variable: Exit counterfactual}

(12)

(13)

(14)

(15)

(16)

(17)

(18)

(19)

(20)

(21)

GDP per capita growth, year T-3 to T-1, average

Government effectiveness, year T-1

Life expentance at birth, year T-1

Inflation

Executive Constraints, year T-1

WEO: Terms of trade, goods, US Dollars, percent change (Percent, Units)

$\begin{array}{cccccccccccc}0.0628^{*} & 0.0614^{*} & 0.0535 & 0.0684^{*} & & & & & & \\ (0.0382) & (0.0345) & (0.0336) & (0.0383) & & & & & & \\ -0.0090 & -0.0453 & -0.0076 & -0.0146 & -0.0011 & 0.0101 & 0.0101 & & & \\ (0.0546) & (0.0518) & (0.0471) & (0.0574) & (0.0535) & (0.0543) & (0.0543) & & & \\ 0.0164 & & & & 0.1776 & 0.1130 & 0.1130 & 0.2213 & 0.2213 & \\ (0.1798) & & & & (0.1877) & (0.1788) & (0.1788) & (0.1959) & (0.1959) & \\ & -0.0200 & & & -0.0192 & & & -0.0173 & -0.0173 & -0.0153 \\ & (0.0180) & & & (0.0214) & & & (0.0218) & (0.0218) & (0.0228)\end{array}$

L\&V: Dummy that takes the value 1 if the country had

any kind of financial crisis

Polity: Political Competition ; Political Competition

$-0.0184$

- $\quad-\quad+$

Constant

(0.1522)

$-3.8687^{*}-3.8025^{*} \quad-3.4183 \quad-4.0160^{*}$

$\begin{array}{llll}(2.2740) & (2.1185) & (2.0823) & (2.327\end{array}$

$-0.8429$

0.0690

$(0.1523)$

$56 \quad 47$

$(0.9333) \quad(0.9093) \quad(0.9093)$

$\begin{array}{lll}-0.9837 & -0.9837 & -0.5333\end{array}$

$\begin{array}{lll}0.8763) & (0.8763) \quad(0.9889)\end{array}$

Observations

46

$47 \quad 44$

4444

*** $p<0.01,{ }^{* *} p<0.05,{ }^{*} p<0.1$ 
Appendix IV. Entry Cases

\begin{tabular}{|c|c|c|c|c|c|c|c|c|c|c|c|}
\hline Economy & Entry & $\begin{array}{c}\text { Exit } \\
\text { (If Any) }\end{array}$ & $\begin{array}{c}\mathrm{CPIA} \text { at } \\
\text { Entry }\end{array}$ & Mission & Conflict & Economy & Entry & $\begin{array}{c}\text { Exit } \\
\text { (If Any) }\end{array}$ & $\begin{array}{l}\text { CPIA at } \\
\text { Entry }\end{array}$ & Mission & Conflict \\
\hline Syria & 1977 & & 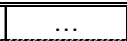 & $\overline{11}$ & & Comoros & 1999 & & 3.9 & & 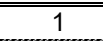 \\
\hline Lebanon & 1978 & & & 1 & & Solomon Islands & 1997 & & 3.2 & & \\
\hline Afghanistan & 1980 & & 3 & & & Central African Republic & 1998 & & 2.8 & 1 & \\
\hline Bolivia & 1983 & 1986 & 2.85 & & & Colombia $\quad \square$ & 1998 & 2006 & & & 1 \\
\hline Nicaragua & 1984 & 1993 & 2.6 & & & Eritrea & 1998 & & 4.5 & & 1 \\
\hline Comoros & 1985 & 1991 & 3.15 & & & Guinea-Bissau & 1998 & & 3.8 & & 1 \\
\hline Congo, Republic of & 1985 & 1988 & 2.55 & & & Chad & 1999 & & 3.4 & & 1 \\
\hline Djibouti & 1985 & & 3 & & & Ethiopia & 1999 & & 3.9 & & 1 \\
\hline Guyana & 1985 & 1991 & 2.7 & & & Kosovo & 1999 & & & 1 & \\
\hline Sierra Leone & 1985 & 2011 & 3 & & & Papua New Guinea & 1999 & 2008 & 3.2 & & \\
\hline Sudan & 1985 & & 3 & & & São Tomé and Príncipe & 1999 & & 2.8 & & \\
\hline Liberia & 1986 & & 2.7 & & & Timor-Leste, Dem. Rep. of & 1999 & & & 1 & \\
\hline São Tomé and Príncipe & 1986 & 1989 & 2.6 & & & Guinea & 2000 & & 3.1 & & \\
\hline Uganda & 1986 & 2006 & 2.7 & & & Kiribati & 2000 & & 3.0 & & \\
\hline Benin -1 & 1987 & 1990 & 2.85 & & & Lao P.D.R. & 2000 & 2009 & 2.8 & & \\
\hline Democratic Republic of the Congo & 1987 & & 3.15 & & & Nepal & 2000 & 2006 & 2.9 & & \\
\hline Ethiopia & 1987 & 1993 & 3 & & & Niger & 2000 & 2004 & 3.0 & & \\
\hline Grenada & 1987 & 1994 & 3 & & & Togo & 2000 & & 2.8 & & \\
\hline Honduras & 1987 & 1993 & 3 & & & Tonga & 2000 & 2009 & 3.0 & & \\
\hline Iraq & 1988 & & $\ldots$ & 1 & & Vanuatu & 2000 & 2008 & 3.0 & & \\
\hline Zambia & 1988 & 1991 & 2.8 & & & Zimbabwe & 2000 & & 3.0 & & \\
\hline Angola & 1989 & 2014 & $\ldots$ & 1 & & Cameroon & 2001 & 2004 & 3.1 & & \\
\hline Costa Rica & 1989 & 1993 & $\ldots$ & 1 & & Côte d'Ivoire & 2002 & & 3.3 & & 1 \\
\hline El Salvador & 1989 & 1996 & $\ldots$ & 1 & & Gambia, The & 2003 & 2009 & 3.2 & & \\
\hline Guatemala & 1989 & 1993 & $\ldots$ & 1 & & West Bank and Gaza & 2005 & & $\ldots$ & 1 & \\
\hline Mozambique & 1990 & 1995 & 4.5 & & 1 & Sri Lanka & 2006 & 2010 & 3.6 & & 1 \\
\hline Solomon Islands & 1990 & 1993 & 3.15 & & & Pakistan & 2009 & 2016 & 3.3 & & 1 \\
\hline Somalia & 1990 & & & & 1 & Yemen & 2009 & & 3.2 & & \\
\hline Sri Lanka & 1990 & 2002 & 4.4 & & 1 & Libya & 2011 & & $\ldots$ & 1 & 1 \\
\hline Congo, Republic of & 1991 & & 3.1 & & & South Sudan & 2012 & & $\ldots$ & 1 & 1 \\
\hline Niger & 1991 & 1996 & 3.05 & & & Madagascar & 2013 & & 3.1 & & \\
\hline Rwanda & 1991 & 2002 & 5.2 & & 1 & Malawi & 2013 & & 3.2 & & \\
\hline Azerbaijan & 1992 & 1995 & $\ldots$ & & 1 & Mali & 2013 & & 3.5 & 1 & 1 \\
\hline Bosnia and Herzegovina & 1992 & & $\ldots$ & 1 & & Marshall Islands & 2013 & & 2.7 & & \\
\hline Croatia & 1992 & 2003 & $\ldots$ & 1 & & Micronesia, Fed. States of & 2013 & & 2.7 & & \\
\hline Georgia & 1992 & 2010 & 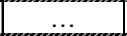 & & 1 & Cameroon & 2014 & & 3.2 & & 1 \\
\hline Haiti & 1993 & & 3.2 & 1 & & Gambia, The & 2015 & & 3.1 & & \\
\hline Tajikistan & 1993 & 2006 & $\ldots$ & & 1 & Maldives & 2015 & & 3.2 & & \\
\hline Algeria & 1994 & 2001 & & & 1 & Myanmar & 2015 & & 3.0 & & \\
\hline Burundi & 1995 & & 4.538795 & & 1 & Papua New Guinea & 2015 & & 3.1 & & \\
\hline FYR Macedonia & 1995 & 2006 & 1010 & 1 & & Tajikistan & 2016 & & 3.1 & & \\
\hline Nigeria & 1995 & 2007 & 2.8 & & & & & & & & \\
\hline
\end{tabular}


Appendix V. Exit Cases

Exit Cases

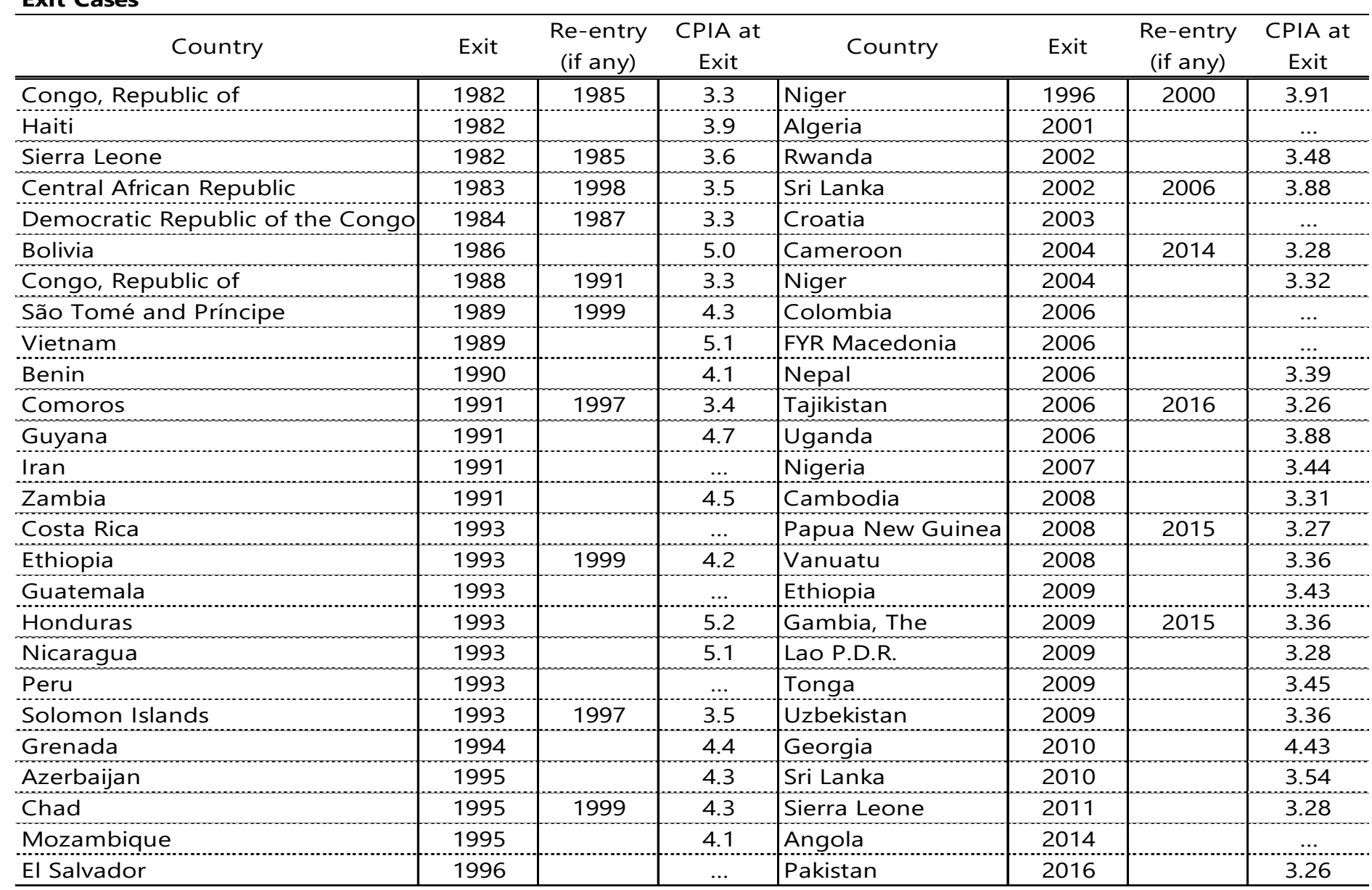


Appendix VI. Entry Counterfactuals

Entry Counterfactuals

\begin{tabular}{|c|c|c|c|}
\hline Country & $\begin{array}{c}\text { Counterfactual } \\
\text { year }\end{array}$ & Country & $\begin{array}{c}\text { Counterfactual } \\
\text { year }\end{array}$ \\
\hline Algeria & 2002 & Myanmar & 1996 \\
\hline Azerbaijan & 2002 & Nepal & 2007 \\
\hline Bangladesh & 1996 & Nicaragua & 2005 \\
\hline Bhutan & 2008 & Niger & 2009 \\
\hline Bolivia & 2005 & Nigeria & 2008 \\
\hline Burkina Faso & 1996 & Pakistan & 1996 \\
\hline Cambodia & 2009 & Papua New Guinea & 2009 \\
\hline Cameroon & 1996 & Peru & 1996 \\
\hline Cameroon & 2005 & Philippines & 1999 \\
\hline Egypt & 2010 & Rwanda & 2003 \\
\hline Ethiopia & 2010 & Sierra Leone & 2012 \\
\hline Honduras & 2014 & Tajikistan & 2007 \\
\hline Indonesia & 1996 & Thailand & 2005 \\
\hline Iran & 1996 & Turkey & 2001 \\
\hline Iran & 2005 & Uganda & 2007 \\
\hline Kenya & 2001 & Uzbekistan & 2010 \\
\hline Kyrgyz Republic & 2003 & Vietnam & 2000 \\
\hline Lao P.D.R. & 2010 & Yemen & 1996 \\
\hline Madagascar & 1996 & Yemen & 2003 \\
\hline Malawi & 2005 & Zambia & 1996 \\
\hline Mali & 1996 & Zambia & 2003 \\
\hline Mauritania & 2006 & Zambia & 2009 \\
\hline Moldova & 2006 & & \\
\hline
\end{tabular}




\section{Appendix VII. Exit Counterfactuals ${ }^{48}$}

Exit Counterfactuals

\begin{tabular}{l|c|l|c}
\hline Country & $\begin{array}{c}\text { Counterfactual } \\
\text { year }\end{array}$ & Country & $\begin{array}{c}\text { Counterfactual } \\
\text { year }\end{array}$ \\
\hline \hline Angola & 2006 & Liberia & 2010 \\
\hline Bosnia and Herzegovina & 1996 & Macedonia, FYR & 2001 \\
\hline Cambodia & 1999 & Mali & 2014 \\
\hline Chad & 2000 & Micronesia & 2014 \\
\hline Comoros & 1998 & Nepal & 2001 \\
\hline Comoros & 2010 & Pakistan & 2010 \\
\hline Congo, Republic of & 2009 & Papua New guinea & 2000 \\
\hline Djibouti & 1999 & Sao Tome and Principe & 2000 \\
\hline Eritrea & 2001 & Sierra Leone & 2004 \\
\hline Eritrea & 2008 & Solomon Islands & 1998 \\
\hline Gambia, The & 2004 & Solomon Islands & 2001 \\
\hline Georgia & 1996 & Sri Lanka & 1996 \\
\hline Georgia & 2003 & Syria & 1996 \\
\hline Guinea-Bissau & 2000 & Timor-Leste & 2000 \\
\hline Guinea-Bissau & 2003 & Timor-Leste & 2009 \\
\hline Guinea-Bissau & 2014 & Togo & 2001 \\
\hline Haiti & 2013 & Togo & 2006 \\
\hline Kiribati & 2001 & Tonga & 2003 \\
\hline Kosovo & 2006 & Uganda & 1996 \\
\hline Lao P.D.R. & 2001 & Vanuatu & 2001 \\
\hline Lao P.D.R. & 2004 & Zimbabwe & 2013 \\
\hline & & & \\
\hline
\end{tabular}

${ }^{48}$ As in the main text, we impose at least three-year blank period between two counterfactuals. 


\section{Appendix VIII. Case Studies ${ }^{49}$}

This appendix provides case studies of two countries: Rwanda and Uganda, derived from existing studies by Fund staff. Both countries achieved sustained exit from state fragility or a conflictaffected case during the 2000s. The case studies highlight fiscal reforms, macroeconomic policies, and capacity development issues that critically facilitated their successful exit.

\section{Rwanda}

Political commitment, accountability, reform ownership, and the support of international partners helped Rwanda to sustain reforms efforts over a long period after regaining political stability. The reforms have supported sustained growth, macroeconomic stability, increased tax revenue, strengthened institutions, and improved social inclusion. These helped Rwanda's successful exit from fragility.

\section{Strong progress made in political stability, coupled with reforms to build institutions and resilience, has helped Rwanda to achieve sustained exit from fragility since the early 2000 s (Gelbard et al., 2015). Rwanda regained political stability with the formation of a national government in July 1994, leaving behind a period with weak institutions (e.g., CPIA was only slightly above 2, well below the threshold 3.2) and macroeconomic instability. Since then, Rwanda managed to rebuild essential institutions in the areas of revenue administration, budget, and banking. Broad ownership of policies, imbedding clear accountability tools, maintaining clear goals and innovation made Rwanda's post conflict institutions robust (Redifer et al., 2020). Also, aid from the international community was important for building resilience, including the resumption of growth and the creation of more fiscal space for public investment. These developments fostered sustained growth since the mid-1990s. Together with increased tax revenue as a result of the reforms, the reduced debt burden, thanks to the successful HIPC and MDRI, created fiscal space to increase social and priority spending.}

\section{Critical fiscal reforms included building tax capacity and rebuilding the PFM systems to support transparency, accountability, and inclusiveness. Building tax capacity, critical to} improve state building and development (Akitoby et al., 2020), focused on (i) tax administration measures to utilize information management systems and improve tax compliance, and (ii) tax policy measures to raise the rates of several indirect taxes. PFM reforms aimed at reinstituting the budget process with parliament adopting annual budget laws since 1998 and rebuilding its PFM system by the mid-2000s. These PFM reforms provided the necessary systems to facilitate donor support through national budgets (Gelbard et al., 2015).

International support, including the IMF, has helped Rwanda to keep resilience and build its institutional capacity. Overall, the Fund played a catalytic role in mobilizing assistance from donors and the creation of the key fiscal institutions (IEO, 2018), through Fund-supported programs and technical support. These Fund-supported programs aimed at enhancing revenue efforts to create fiscal space for critical development spending and boost international reserves

\footnotetext{
49 The analysis used in these case studies is based on Gelbard et al., (AFR departmental paper, 2015), IOE report (2018), Akitoby et al. (2019, 2020), Redifer et al. (2020), and various Article IV and program staff reports.
} 
in the face of adverse external shocks, which have helped maintain resilience in Rwanda (IEO, 2018, and IMF country reports). In addition, IFls and bilateral donors provided technical support in several areas, including revenue mobilization, PFM, and monetary and exchange rate management.

\section{Reform efforts amid political stability, backed by the support from the international community, have helped improve resilience, governance and institution, and social inclusion in Rwanda after its exit from fragility.}

- Rwanda's post-conflict economic recovery was strong, with low inflation and a comfortable level of international reserves (IEO, 2018).

- Broad-based institituonal reforms helped Rwanda achieve sustained improvement in its governance and key institutions over time (Gelbard et al., 2015): e.g., Rwanda's CPIA score increased from only 2.2 at mid-1990s to consistently above 3.5 after the exit.

- Increased revenue supported priority and development spending. Rwanda's tax-to-GDP ratio increased from 9.7 percent in 2000 to over 13 percent on average during 2010-13 after the tax reforms (Akitoby et al., 2019).

- Social indicators demonstrate substantial improvement: e.g., priority spending increased from 4 percent of GDP in 1999 to 12-14 percent during 2008-12 (Gelbard et al., 2015); and the poverty rate declined from 75 percent (on average) in 1992-2000 to around 59 percent in 2010-16.

\section{Uganda}

Enhanced macroeconomic policy framework, supported by capacity development provided by IFIs and donors, helped Uganda to strengthen its institutions and maintain prudent macroeconomic management after the end of recurrent civil wars and conflicts. Increased domestic revenues, together with strong macroeconomic performance, improved social conditions since the mid-2000s, and provided support for Uganda's sustained exit from fragility.

Uganda exited from fragility around the middle of the 2000s, as conflicts subsided. Uganda experienced recurrent civil wars and external conflicts since the 1970s. The peace talks which started in 2006 paved the way to end the 20-year conflict in northern Uganda, exit fragility, and regain political stability. Since then, Uganda achieved strong macroeconomic performance, which was supported by prudent macroeconomic policies, a sound banking sector, and substantial donor assistance (IMF, 2010; Akitoby et al., 2019). Also, the Ugandan government strengthened domestic revenue mobilization to build fiscal space for development and priority spending, while reducing reliance on donor funds (e.g., the National Development Plan, 2010/11-2014/15).

\footnotetext{
Key fiscal reforms focused on raising tax revenues to secure fiscal space and strengthening public financial management. On the revenue front, as noted in Akitoby et al. (2019), the reforms focused on raising tax revenue by: eliminating tax exemptions, making income tax more progressive, and reforming excise taxes to expand the tax base; and improving tax administration through better segmentation of taxpayers (e.g., establishing a high net worth individuals unit and strengthening the medium-sized taxpayer office) and widely using electronic tax services. Reforms in PFM focused on strengthening spending controls, including by setting up a Treasury Single Account.
} 
International technical support helped to strengthen the policy framework, which contributed to macroeconomic stability (Gelbard et al., 2015). While Uganda did not have a Fund financing arrangement since 2006 (and until the COVID-19 crisis), the IMF did provide policy advice, including through three Policy Support Instrument programs (PSI), and the Fund and other donors also provided technical support to help the authorities to strengthen their policy framework, including support on: developing the monetary policy framework and reform of its financial system; and revenue mobilization and PFM reforms (IMF and AFRITAC East).

Improved political stability provided the basis for implementing reforms to strengthen the macroeconomic policy framework, which have helped to build resilience. ${ }^{50}$

- After the start of the peace talks, Uganda broadly maintained strong macroeconomic performance and prudent macroeconomic management for over a decade (Akitoby et al., 2019).

- Notable improvement in political stability and resilience since the mid-2000s indicates the shift in the political atmosphere to support reforms and prudent macroeconomic policies, while CPIA stayed well above the threshold (slightly less than 4, against the threshold 3.2).

- Fiscal reform efforts have resulted in increased tax revenue in percent of GDP from slightly below $91 / 2$ percent of GDP on average before the start of the peace talks to over 11 percent on average during the second half of the 2010s.

- Strong macroeconomic performance and fiscal reforms have created space for investments in health and education, which improved living standards and reduced poverty (IMF, 2007, 2013): e.g., the share of the people below the poverty line declined substantially from 65 percent of the population in 2002 to 36 percent in 2012.

\footnotetext{
50 However, it is worth menitioning that some of the progress has been reversed after the PSI programs ended in 2017. For instance, tax exemptions increased and governance indicators (e.g., the control of corruption index) worsened-resulting in the gradual withdrawal of on-budget donor support (IMF, 2017; 2019; 2020).
} 